\title{
Graptolites from the Benton area of west-central New Brunswick and their regional significance
}

\author{
L.R. Fyffe, Mineral Resources Branch, Department of Natural Resources \\ P.O. Box 6000, Fredericton, New Brunswick E3B 5H1
}

W.H. Forbes, University of Maine, Presque Isle, Maine 04760

J. Riva, Laval University, Quebec City, Quebec GlK 7P4

\begin{abstract}
Graptolites in black slate underlying volcanics along Eel River near Benton, $20 \mathrm{~km}$ south of Woodstock, New Brunswick belong to the Clonograptus tenellus Zone of the upper Tremadoc Series. They are essentially the same age as graptolites from the Cookson Formation of southern New Brunswick.

The Belle Lake Slate overlies the same volcanics, and on Belle Brook, $12 \mathrm{~km}$ southwest of Benton, contains graptolites referred to the Nemagraptus gracilis Zone of the Caradoc Series. The Belle Lake Slate correlates with an unnamed sequence of greywacke and slate in the Hayesville area of
\end{abstract} central New Brunswick.

The Ordovician volcanics and overlying sedimentary rocks are the same general age as a limestone facies found to the east and northeast of Woodstock. The limestones were deposited in shallowwater at varying distances from volcanically active areas.

The presence of lithologically similar Lower Ordovician and older rocks in the Benton area of west-central New Brunswick and in the Cookson Formation of southern New Brunswick allows both areas to be included in the same suspect terrane.

A $20 \mathrm{~km}$ au sud de Woodstock (Nouveau-Brunswick) on trouve, dans une ardoise noire recouverte de roches volcaniques, des graptolites qui appartiennent à la zone clonograptus tenellus de la série du Trémadocien supérieur. Ceș graptolites datent essentiellement de la même période que les graptolites de la formation de Cookson du sud du Nouveau-Brunswick.

A $12 \mathrm{~km}$ au sud-ouest de Benton, le long du ruisseau Belle, les roches volcaniques mentionnées ci-haut sont recouvertes par l'ardoise Belle Lake qui contient des graptolites de la zone à Nemagraptus gracilis de la série du Caradocien. L'ardoise Belle Lake est correlée avec une séquence de grauwacke et d'ardoise que $l^{\prime}$ on retrouve dans la région de Hayesville au centre du NouveauBrunswick.

Les roches volcaniques ordoviciennes et les roches sédimentaires qui les recouvrent ont environ le même âge qu'un faciès de calcaire situé à l'est et au nord-est de Woodstock. Les calcaires ont. été déposés en eau peu profonde à des distances variables d'une région volcaniquement active.

La présence de roches lithologiquement semblables, certaines datant de 1'Ordovicien inférieur, d'autres plus anciennes, dans la région de Benton au centre-ouest du Nouveau-Brunswick et dans la formation de Cookson au sud du Nouveau-Brunswick présupposé une parenté entre les deux régions.

[Tradult par le journal]

\section{INTRODUCTION}

The two new fossil localities discussed in this paper were discovered by searching the ground in the vicinity of occurrences reported in the geologic literature over eighty years ago. While one of us (L.R.F.) was researching some old reports to prepare a summary of stratigraphic terminology in New Brunswick, it became apparent that L.W. Bailey had found graptolite fragments near Maxwe11, $30 \mathrm{~km}$ southwest of Woodstock (Fig. 1). A one day search in the area in late summer of 1982 resulted in the discovery of well preserved graptolites on Belle Brook (Fig. 2).

MARITIME SEDIMENTS AND ATLANTIC GEOLOGY

$19,117-125(1983)$
A better documented graptolite locality discovered by Bailey near Benton, 20 $\mathrm{km}$ south of Woodstock, had not been successfully re-collected despite attempts by several geologists. At the Nato Advanced Study Institute Meeting on the Caledonide Orogen held in Fredericton in August 1982, W. H. Poole and R. B. Neuman suggested that Forbes attempt to collect the site in the coming fall.

This paper is intended as a tribute to the pioneering work of L.W. Bailey and G.F. Mat thew who began their geological survey of west-central New Brunswick one hundred years ago (Bailey, 1885: In Report of Progress for 1882-83-84).

HISTORICAL PERSPECTIVE

In the summer of 1900 , while attempt- 


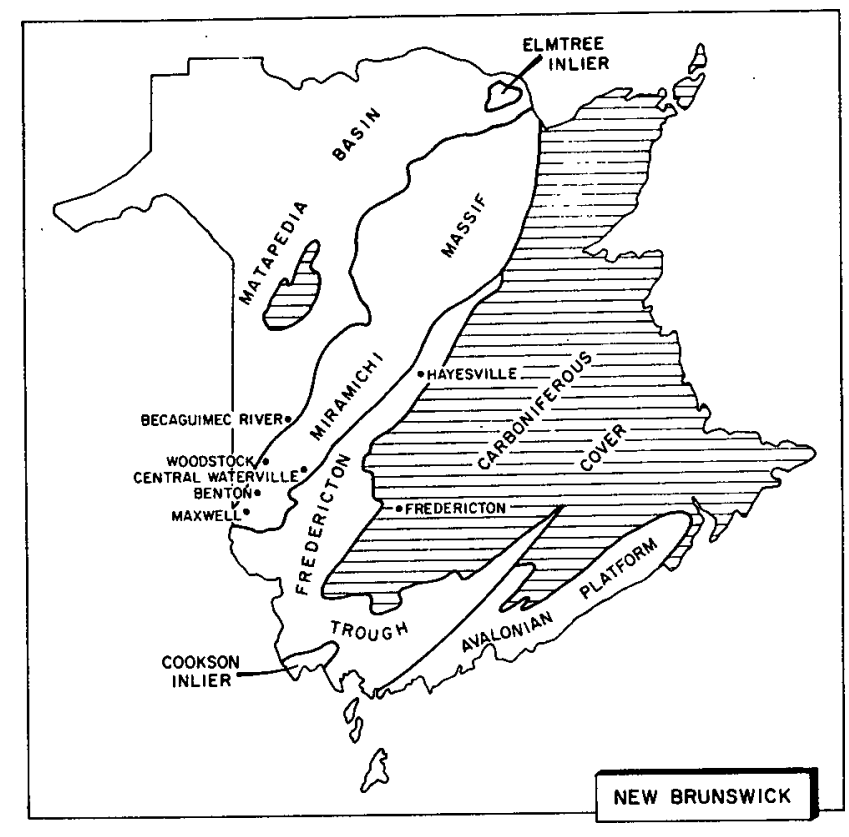

Fig. 1 - Tectonostratigraphic zones of New Brunswick.

ing to delimit the extent of fossiliferous Silurian rocks in west-central New Brunswick, Bailey $(1901,1903)$ discovered graptolites in black slate on Eel. River at Benton. He reported that both Matthew and Ami regarded them as identical to Dictyonema flabelliforme (Eichwald) found on Navy Island in Saint John Harbour (Matthew 1891). Bailey's discovery confirmed the Cambro-Ordovician age of the Benton rocks which was previously based only on their lithologic characteristics (Bailey 1885, pp. 16-17).

Bailey (1901, pp. 148-149) described another belt of slate overlying volcanics and quartzite in the vicinity of Monument Settlement (close to the present day community of Maxwe11, $12 \mathrm{~km}$ southwest of Benton (Fig. 2). Although no fossils had been recovered, Bailey considered the Monument Settlement beds to be equivalent to those of the fossiliferous Benton locality. In the summer of 1904, Bailey (1906) recovered graptolites near Monument Settlement but their poor preservation prevented a definite age assignment (Ami 1906). Nevertheless, Bailey maintained that the two areas of slate were generally of the same age.
Recent mapping in west-central New Brunswick has led to the establishment of a detailed stratigraphic framework (Venugopal 1978, 1979; Lutes 1979) where previously only reconnaissance maps existed (Patterson 1957; Tupper 1957).

\section{STRAT IGRAPHY}

New Brunswick has been divided into the following tectono-stratigraphic zones from northwest to southeast (Fyffe et al. 1981): Matapedia Basin containing Upper Ordovician to Lower Devonian sedimentary rocks and Upper Silurian to Lower Devonian volcanic rocks; Elmtree Inlier containing Ordovician ophiolite; Miramichi Massif underlain by Cambrian to mid-Ordovician sedimentary, and Ordovician volcanic rocks; Fredericton Trough containing Silurian to Lower Devonian sedimentary rocks with abundant volcanics along its southern margin; Cookson Inlier underlain by CambroOrdovician sedimentary rocks; and Avalonian Platform containing Precambrian rocks unconformably overlain by platformal Cambro-Ordovician sediments (Fig. 1).

A brief description of the stratigraphic divisions within the southwestern portion of the Miramichi Massif, in which the new graptolite discoveries occur, is given below.

The Cambro-Ordovician rocks of the Benton area (Fig. 2) have been divided into three formations. In ascending order these are: unnamed quartzite-slate unit, the Pocomoonshine Volcanics, and the Belle Lake Slate. The unnamed unit consists of light green to grey quartzite interbedded with light green to grey slate, and minor maroon and black slate. The black slate containing local thin beds of quartzite is exposed along Eel River southeast of Benton. It apparently interfingers eastward with thick beds of green quartzite and slate (Venugopal 1978).

The Pocomoonshine Volcanics comprise felsic tuffs and mafic volcanic rocks interbedded with red ferromanganiferous slate. The volcanics overlie black slate of the unnamed unit on Eel River 
but overlie massive quartzite farther east along the Trans-Canada Highway.

The Belle Lake Slate conformably overlies the Pocomoonshine Volcanics and extends from south of Benton westward to Maxwell and Belle Brook. It comprises an interbedded sequence of dark grey slate and greywacke. An outlier of Siluro-Devonian sedimentary and volcanic rocks unconformably overlies the Cambro-Ordovician succession.

The stratigraphy of the Cambro-Ordovician rocks in west-central New Brunswick was established during the recently completed mapping program by comparison with the well-documented section north of Hayesville in central New Brunswick (Poole 1963, Neuman 1968). No fossils were found in the Benton area during this program to confirm the correlation but Ordovician volcanics were traced intermittently along the southeastern margin of the Miramichi Massif from Hayesville to Benton (Fyffe 1982a).

\section{DESCRIPTION AND AGE OF FAUNA}

No difficulty was encountered in 1occating the Benton exposure on Eel River as it is fairly well described by Bailey (1901). The outcrop of black slate is on the east bank of the river just down-

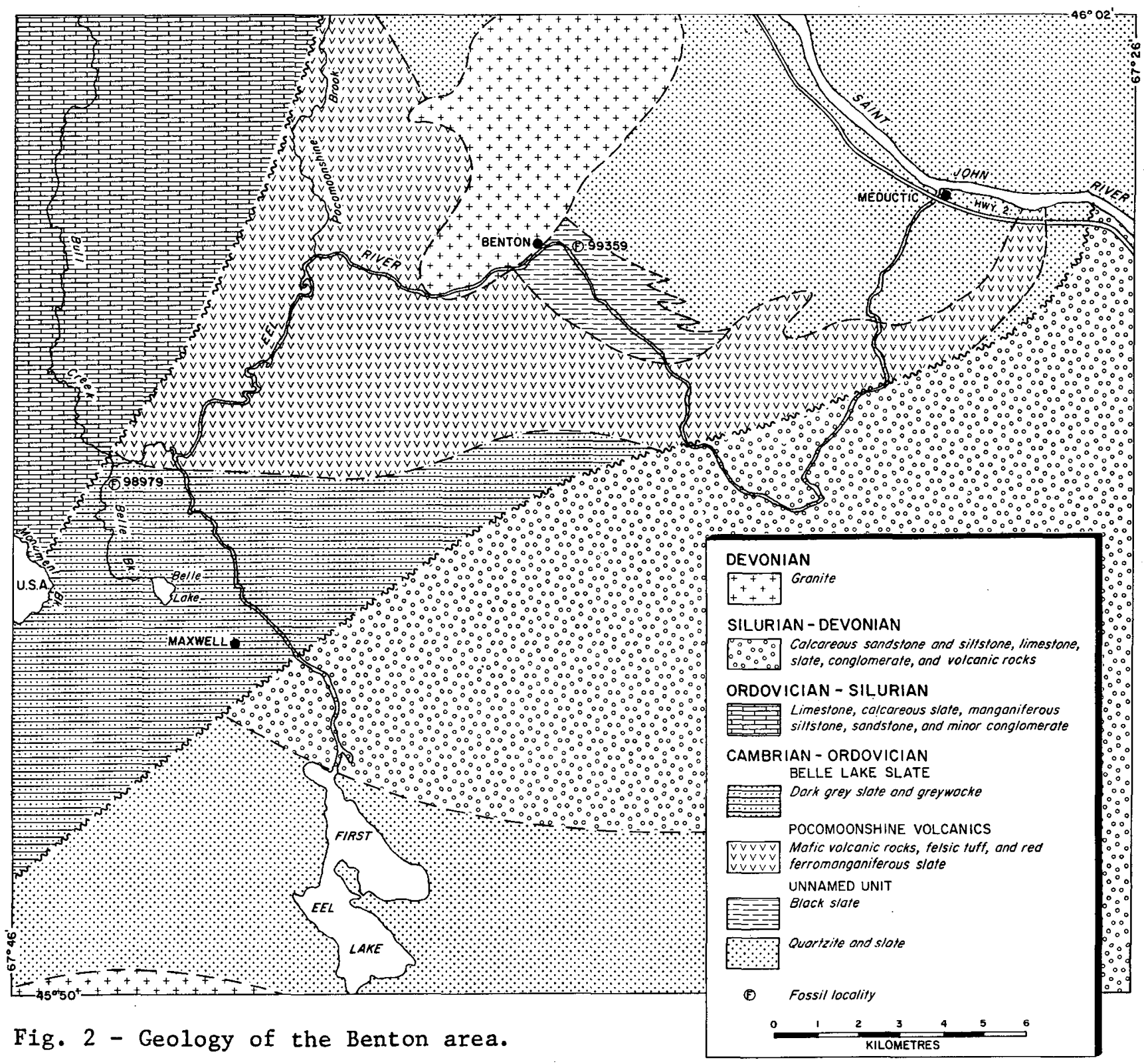


stream from the bend at Benton. Forbes collected specimens near the southeast margin of a dyke located near the centre of the exposure.

The Benton collection (Geological Survey of Canada locality 99359, latitude $45^{\circ} 59^{\prime} 15^{\prime \prime} \mathrm{N}$, longitude $67^{\circ} 36^{\prime}$ low) contains the following graptolites.

\section{Adelograptus hunnebergensis (Moberg) Clonograptus tenellus (Linnarson)}

These graptolites are restricted to the upper Tremadoc (Fig. 3) and are identical in age to those from black slate of the Cookson Formation on Cookson Island in Passamaquoddy Bay, southwestern New Brunswick (Cumming 1967).

Abundant fecal pellets referable to Tomaculum (Groom) are also present in the collection (Pickerili, University of New Brunswick, personal communication 1982). This trace fossil has been reported from many North American and European sequences and is commonly regarded to be indicative of Ordovicianaged strata (Häntzschel 1975).

No specimens of Dictyonema were found during the recent collecting. The position of Bailey's collection with respect to the above is not known, but Bailey (1901) stated that his fossil-bearing layer is no more than six inches thick and is located in the southern portion of the exposure presumably a few metres southeast of the present graptolite locality. Bailey $(1901,1903)$ reported that his specimens very closely resemble Dictyonema flabelliforme (Eichwald) which is of early Tremadocian age. Examination of Bailey's original Dictyonema specimens, stored in the Geology Department of the University of New Brunswick, allowed identification only at the genus level as the proximal ends were absent.

No description of the Monument Settlement site was given by Bailey. However in the same general area, Tupper (1957) showed a fossil location just downstream from the junction of Belle Brook and Bul1 Creek that Anderson (1968, p. 20) reported as Ordovician. The outcrop shown near the mouth of Belle Brook by Tupper could not be relocated during a visit to the area. The nearest expo- sure, consisting of greywacke and slate of the Belle Lake Slate, occurs on Bull Creek about $200 \mathrm{~m}$ northwest of Belle Brook but no fossils were found there. Graptolites were found, however, in abundance along Belle Brook about $300 \mathrm{~m}$ from its mouth in an outcrop on the side of a woodroad that follows the east bank of the stream.

The Belle Brook collection (Geological Survey of Canada locality 98979, latitude $45^{\circ} 56^{\prime} 15^{\prime \prime} \mathrm{N}$, longitude $67^{\circ} 44^{\prime}$ $10^{\prime \prime} W$ ) from grey slate of the Belle Lake Slate contains the following species. Climacograptus bicornis (Ha11) orthograptus calcaratus (Lapworth)

Pseudoclimacograptus scharenbergi

Climacograptus brevis brevis (Lapworth)

(E11es and Wood)

Corynoides calicularis (Hopkinson)

?Cryptograptus tricornis (Carruthers)

?Nemagraptus exilis Lapworth in Gurley 1896

This assemblage is common to both the Nemagraptus gracilis and Diplograptus multidens Zones, but the lack of Dicellograpti and Didymograptus together with the occurrence of Corynoides indicates the collection belongs to the upper gracilis Zone (Fig. 3).

\section{REGIONAL CORRELATION}

The relatively large number of Ordovician fossil localities now known from central New Brunswick allows comparison of widely separated stratigraphic sections in the Benton, Hayesville, Becaguimec River, and Central Waterville areas, and permits improved reconstruction of Ordovician paleogeography (Figs . $1,3)$.

The graptolites from the Belle Lake Slate on Belle Brook and from the unnamed unit on Eel River establish abiostratigraphic correlation with Ordovician rocks in the Hayesville area. An unfossiliferous greywacke and slate unit in the Hayesville area is virtually identical in age to the lithologically similar Belle Lake Slate since the Hayesville greywacke is underlain by a thin unit of black slate containing grapto- 
lites of the Nemagraptus gracilis Zone (Irrinki 1980).

The black slate unit is underlain by a thin unit of red ferromanganiferous slate; these two units are intercalcated with mafic volcanics to the north (Poole 1963). Similar red slates are associated with the volcanics in the Benton area (Venugopal 1978, 1979).

The red slate in the Hayesville area lies with erosional contact upon calcareous siltstone containing thin interbeds of felsic tuff (Poole 1963, Irrinki 1980) and Arenigian brachiopods (Neuman 1968). The fossiliferous siltstone is underlain by a thick succession of quartzite and slate. To the north, the siltstone is replaced by conglomerate containing quartzite pebbles derived from the underlying quartzite-slate unit (Crouse 1981).

According to Neuman (1968), the calcareous siltstone and tuffs together with similar rocks in eastern Maine represent shallow-water shoreline deposits adjacent to volcanic islands. In contrast, the older graptolite-bearing Tremadocian black slate of the Benton area shows no evidence of contemporaneous volcanicity.

The mid-Ordovician greywacke-slate unit of the Hayesville area and Belle Lake Slate of the Benton area were deposited in deep basins by turbidity currents carrying volcanic detritus derived from erosion of the nearby volcanic is lands. The paleontological evidence thus clearly demonstrates that in central New Brunswick volcanic activity began in the Arenigian, peaked in the Llanvirnian to early Caradocian, and waned in mid-Caradocian time.

A quite different mid-Ordovician stratigraphy is present on the eastern margin of the Matepedia Basin to the northwest of the Benton-Hayesville volcanic belt. In the Becaguimec area, a sequence of interbedded lithographic limestone, crystalline limestone, and black chert occurs in small inliers unconformably overlain by Upper Ordovician and Silurian conglomerates (St. Peter 1982). It is in one of these inliers exposed on the Becaguimec River that
Matthew in 1879 discovered a fossil 10cality that yielded several small brachiopods and the mid-Ordovician trilobite Cryptolithus (Bailey 1886, Hamilton 1965). Plant-bearing conglomerate and monograptid-bearing siltstone reported by Bailey (1887) to unconformably overlie the Ordovician limestone along the river are actually in fault-contact with it.

Conodonts recovered from several horizons by G. Nowlan of the Geological Survey of Canada indicate that the limestone sequence extends in age from Llanvirian to early Caradocian (St. Peter 1982). Limestone was thus being deposited in the Becaguimec area during periods of extensive volcanism farther south (Fig. 3). The limestone was laid down in relatively shallow water (St. Peter 1982) possibly off the shore of a nonvolcanic island.

Limestone within the Miramichi terrane near Central Waterville (Bailey 1901, 1903; Hamilton 1965; Anderson 1968; Venugopal 1979) to the northeast of Benton is Llanvirian/Llaneilian, the same age as the Becaguimec occurrences (Nowlan 1981, St. Peter 1982) but differs from it in having an abundance of interbedded greywacke containing sparse volcanic fragments. Presumably this reflects the closer proximity of the Central Waterville area to the BentonHayesville volcanic source area.

\section{TECTONIC IMPLICATIONS}

The regional extent of tectonic events in this part of the northern Appalachians can be ascertained by comparing the stratigraphic columns in west-central New Brunswick with those on the opposite side of the Matapedia Basin in eastern Maine, and across the Fredericton Trough in southern New Brunswick.

Pavlides (1968) and Roy and Mencher (1976) considered mid-Ordovician volcanic rocks on the western margin of, and the calcareous flyschoid rocks within the Matapedia Basin to be coeval. They interpreted deposition to be continuous within the basin from Caradocian to Early Silurian time. Rickards and Riva (1981) showed that the paleon- 


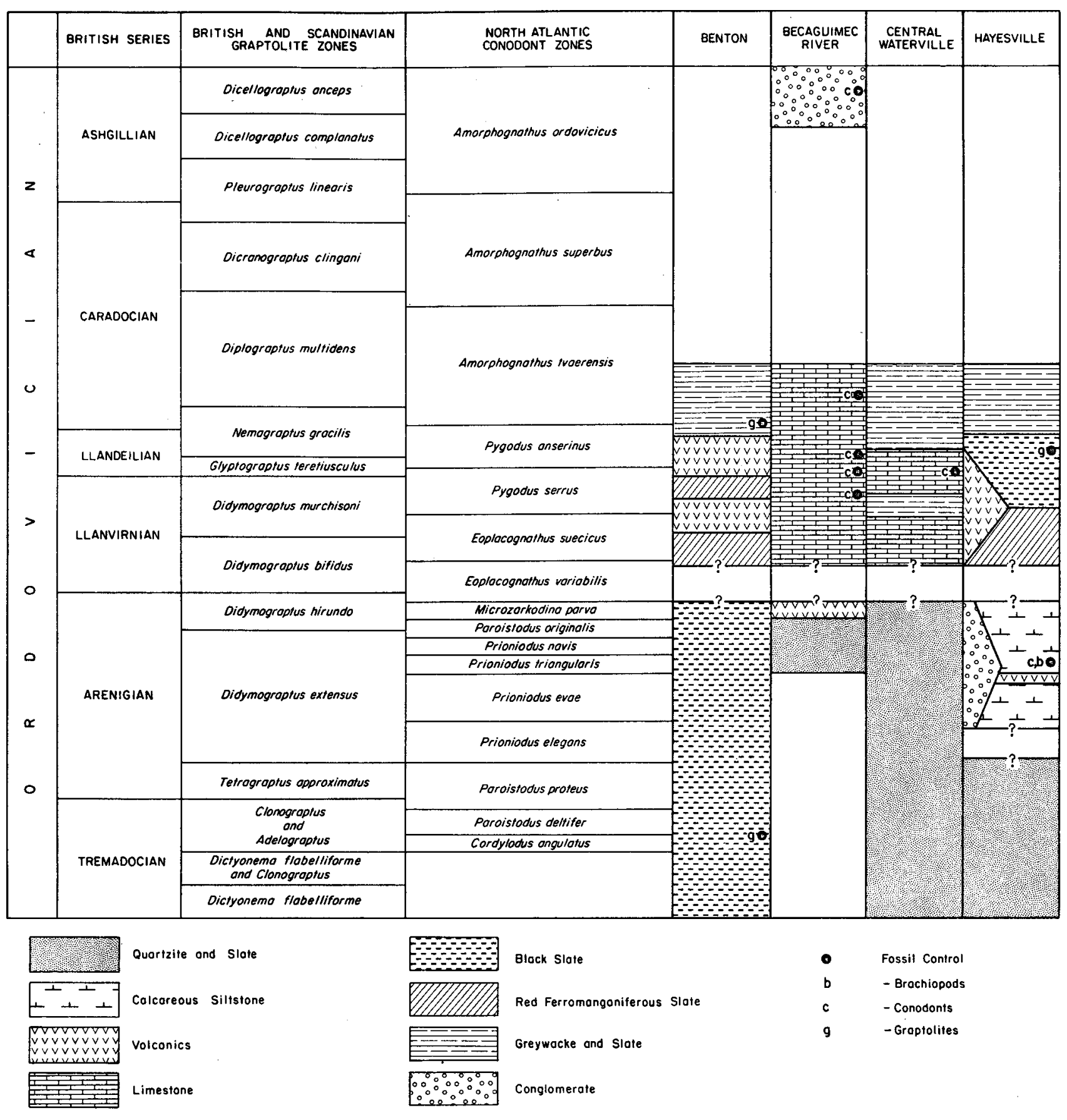

Fig. 3 - Correlation chart for the Ordovician of central New Brunswick (zones after Barnes et al. 1981).

tological basis for the Caradocian age of the calcareous rocks was erroneous and that they were, in fact, Early Silurian. This later conclusion is confirmed in the Becaguimec River area on the eastern margin of the basin where an unconformity separates the mid-Ordovician limestone sequence from over- lying conodont-bearing late Ashgillian calcareous conglomerate representing a shallow-water facies of the calcareous flysch found farther west (St. Peter 1982).

The unconformity restricts Taconian uplift within the Matapedia Basin of west-central New Brunswick to the inter- 
val following deposition of the early Caradocian limestone and their resubmergence in the late Ashgillian. This contrasts with the Late Silurian submergence of Cambro-Ordovician rocks on the northwestern margin of the Massif (Helmstaedt 1971), and Cookson Inlier (Pickerill 1976) within the Fredericton Trough (Fig. 1). However, formation of the Fredericton Trough, which contains Silurian clastic flyschoid rocks ranging in age from Llandoverian to Ludlovian along its northwestern margin (Poole 1963), evidently began about the same time as the resubmergence of the pre-Ashgillian rocks of the Matapedia Basin. The Fredericton Trough would have formed at this time by foundering of Cambro-Ordovician basement as exposed to the northwest at Benton and to the south in the Cookson Inlier. There is little evidence to support the existence of ocean crust flooring in the Trough as proposed by Mckerrow and Ziegler (1971).

The presence of coeval and 1ithologically similar rocks possessing a similar tectonic history in the Miramichi Massif at Benton (Fyffe 1982b) and in the Cookson Inlier of southern New Brunswick (Stringer and Pajari 1982) makes it unlikely that the Fredericton Fault, which occurs along the axis of the Fredericton Trough, represents a terrane boundary as suggested by Williams and Hatcher (1982).

In the summer of 1983, graptolites were discovered in black slate underlying felsic tuff on the Trans-Canada Highway $3 \mathrm{~km}$ east of Meductic (G.S.C. Locality 99657). The presence of Tetragraptus cf. amii and Didymograptus sp. are indicative of the mid- to late Arenig and confirms that black slate of the Benton area is a facies equivalent of the calcareous siltstone of the Hayesville area as suggested in Figure 3 .

\section{ACKNOWLEDGEMENTS}

We wish to thank G. Nowlan and R. Neuman for their critical reviews of the manuscript. C. St. Peter also suggested improvements to the final draft.
The Geological Survey of Canada is acknowledged for its paleontological assistance. D. Blair and T. Murray typed the manuscript and $R$. Phillips drafted the figures.

AMI, H.M. 1906. Preliminary list of fossils collected by Professor L. W. Bailey from various localities in the Province of New Brunswick during 1904. Appendix to Summary Report of L.W. Bailey. Geological Survey of Canada, Summary Report for 1904, Part A, pp. 289-292.

ANDERSON, F.D. 1968. Woodstock, Millville, and Coldstream map-areas, Carleton and York Counties, New Brunswick. Geological Survey of Canada, Memoir 353, 69p.

BAILEY, L. W. $188^{\circ} 5$. Report on explorations and surveys in portions of York and Carleton Counties, New Brunswick. Geological Survey of Canada, Report of Progress for 1882-83-84, Part G, $31 \mathrm{p}$.

1886. Report on explorations and surveys in portions of the Counties of Carleton, Victoria, York, and Northumberland, New Brunswick. Geological Survey of Canada, Summary Report for 1885, Part G, 30p.

\section{On the Silurian}

system of northern Maine, New Brunswick, and Quebec. Transactions of the Royal Society of Canada, Section 4, Volume 4, pp. 35-41.

correlations in New Brunswick. Transactions of the Royal Society of Canada, Section 4, Volume 7, Pp. 143-150.

York and Carleton Counties, New Brunswick. Geological Survey of Canada, Summary Report for 1900, Part A, pp. 146-151.

1906. Fossil occurrences and certain economic minerals in New Brunswick. Geological Survey of Canada, Summary Report for 1904, Part A, pp. 279-289. 
BARNES, C.R., NORFORD, B.S., and SKEVINGTON, D. 1981. The Ordovician System in Canada. International Union of Geological Sciences. Publication No. 8, 27p.

CROUSE, G.W. 1981. Geology of parts of Burnthill, Clearwater, and McKiel Brooks (map-areas $\mathrm{K}-14, \mathrm{~K}-15$, and $\mathrm{K}-$ 16). Minera1 Resources Branch, New Brunswick Department of Natural Resources, Map Report 81-5, 46p.

CUMMING, L.W. 1967. Geology of the Passamaquoddy Bay region, Charlotte County, New Brunswick. Geological Survey of Canada, Paper 65-29, 36p.

FYFFE, L.R. 1982a. Geology of Woodstock (sheet 21J). New Brunswick Department of Natural Resources, Map NR-4. dian structural trends in central and northern New Brunswick. In Major structural zones and faults of the northern Appalachians. Edited by $P$. St.-Julien and J. Béland. Geological Association of Canada, Special Paper 24, pp. 117-130.

FYFFE, L.R., PAJARI, G.E., and CHERRY, M.E. 1981. The Acadian plutonic rocks of New Brunswick. Maritime Sediments and Atlantic Geology, Volume 17, No. 1, pp. 23-36.

HAMILTON-SMITH, T. 1972. Stratigraphy and structure of Silurian rocks of the McKenzie Corner area, New Brunswick. Minera1 Development Branch, New Brunswick Department of Natural Resources, Report of Investigation 15, 26p.

HAMILTON, J. B. 1965. Limestone in New Brunswick; Mines Branch, Department of Lands and Mines, New Brunswick, Mineral Resources Report No. 2, 147p.

HÄNTZSCHEL, W. 1975. Trace fossils and problematica. In Treatise on Invertebrate Paleontology, Part W, Miscellanea Edited by C. Telchert. Geological Society of America and The University of Kansas, pp. W1-W296.
HELMSTAEDT, H. 1971. Structural geology of Portage Lakes area, BathurstNewcastle district, New Brunswick. Geological Survey of Canada, Paper 70-28, 52p.

IRRINKI, R.R. 1980. Geology of Kennedy Lakes-Little Dungarvon and South Renous Rivers region (map-areas $\mathrm{M}-13, \mathrm{M}-14$, $\mathrm{M}-15$, and part of M-16). Mineral Resources Branch, New Brunswick Department of Natural Resources, Map Report $80-2,39 p$.

LUTES, G. 1979. Geology of FostervilleNorth and Ee1 Lakes (map-area G-23) and Canterbury-Skiff Lake (map-area H-23). Mineral Resources Branch, New Brunswick Department of Natural Resour ces, Map Report 79-3, 22p.

MATTHEW, G.F. 1891. On a new horizon in the St. John Group. Canadian Record of Science, Volume 4, pp. 339-343.

MCKERRROW, W.S. and ZIEGLER, A. M. 1971. The Lower Silurian paleogeography of New Brunswick and adjacent area. Journal of Geology. Volume 71, pp. 635-646.

NEUMAN, R.B. 1968. Paleogeographic implications of Ordovician shelly fossils in the Magog Belt of the northern Appalachians region. In Studies of Appalachian geology-northern and Maritime. E-An Zen, W.S. White, J.B. Hadley, and J.B. Thompson, Jr. (Editors). New York, Interscience, pp. 35-48.

NOWLAN, G.S. 1981. Some Ordovician conodont faunules from the Miramichi Anticlinorium, New Brunswick. Geological Survey of Canada, Bulletin 345, 35p.

PATTERSON, J.B. 1957. The geology of the Canterbury map-area (west-half). Unpublished M.Sc. thesis, University of New Brunswick, Fredericton, New Brunswick, 59p.

PAVLIDES, L. 1968. Stratigraphic and facies relationships of the Carys Mills Formation of Ordovician and Silurian age, northeast Maine. United States Geological. Survey Bulletin $1264,44 \mathrm{p}$.

PICKERILL, R.K. 1976. Significance of a 
new fossil locality containing a Salopina community in the Waweig Formation (Silurian-uppermost Ludlow/Prido1i) of southwest New Brunswick. Canadian Journal of Earth Sciences, Volume 13, pp. 1328-1331.

POOLE, W.H. 1963. Geology of Hayesville, New Brunswick. Geological Survey of Canada, Map 6-1963.

RICKARDS, R.B. and RIVA, J. 1981.Glyptograptus? persculptus (Salter), its tectonic deformation, and its stratigraphic significance for the Carys Mills Formation of N.E. Maine, U.S.A. Geological Journal, Volume 16, pp. 219-235.

ROY, D.S. and MENCHER, E. 1976. Ordovician and Silurian stratigraphy of northeastern Aroostook County, Maine. Geological Society of America, Memoir 148, pp. 25-52.

ST. PETER, C. 1982. Geology of JuniperKnowlesville-Carlisle area (map-areas I-16, I-17, I-18). Minera1 Resources Branch, New Brunswick Department of Natural Resources, Map Report 82-1 $82 \mathrm{p}$.
STRINGER, P. and PAJARI, G.E. 1982. Deformation of Ordovician and Silurian rocks at Oak Bay and Cookson Island, St. Stephen, New Brunswick (Abstract). Journal of Structural Geology, Volume 4, p. 2.34 .

TUPPER, W.M. 1957. Geology of the Fosterville map-area, York County, New Brunswick. Mines Branch, New Brunswick Department of Lands and Mines.

VENUGOPAL, D.V. 1978. Geology of BentonKirkland, Upper Eel River Bend (maparea G-22). Mineral Resources Branch, New Brunswick Department of Natural Resources, Map Report 78-3, 16p.

1979. Geology of Debec Junction-Gibson Millstream-Temperance Vale-Meductic Region (map-areas G-21, $\mathrm{H}-21, \mathrm{I}-21, \mathrm{H}-22)$. Mineral Resources Branch, New Brunswick Department of Natural Resources, Map Report 79-5, $36 \mathrm{p}$.

WILLIAMS, H. and HATCHER, R.D. 1982. Suspect terranes and accretionary history of the Appalachian orogen. Geology, Volume 10, pp. 530-536. 



\title{
Sediment characteristics of some Nova Scotian beaches
}

\author{
Edward Bryant, Department of Geography \\ University of Wollongong, P.O. Box 1144, Wollongong, Australia 2500
}

\begin{abstract}
A general model exists relating morphology, hydrodynamics and sediment transport behaviour of beach foreshores. This model states that on a reflective foreshore, where wave energy is reflected from the beach face, sediment size grades steeply in value $(0.2 \mathrm{~mm} / \mathrm{km})$ along the beach face, downdrift and towards highest energy. This grading is temporally stable. On a dissipative foreshore, where wave energy is dissipated across a surf zone, size gradings are weakly developed $(0.1 \mathrm{~mm} / \mathrm{km})$ and have a high degree of temporal variability. The model applies to high energy, swell-dominated, compartmentalized beaches with stable sea level and no sediment input. Most of the beaches studied in Nova Scotia, where sea level is rising, fit within this model; however the effects of source dominance, low wave energy levels and edge wave triggering processes must be considered.

L'effet combiné des facteurs agissant sur l'estran, soit la morphologie, l'hydrodynamique et le mouvement des sédiments, est traité par un modèle général. Ce modèle propose que le long d'un estran réfléchissant, lè où l'énergie de la houle est réfléchie par le rivage, la granulométrie des matériaux crô̂t rapidement $(0.2 \mathrm{~mm} / \mathrm{km})$ en direction de la dérive et vers les zones à haute énergie. Ce granoclassement est temporellement stable. Le long d'un rivage où l'énergie de la houle est dissipée par une zone de brisants, le gradient granulométrique est moins bien exprimé $(0.1 \mathrm{~mm} / \mathrm{km})$ et temporellement très variable. Ce modèle s'applique aux plages compartimentées, dominèes par la houle, où l'énergie du milieu est haute, le niveau de la mer stable et 1'apport de sédiments nul. En Nouvelle-Ecosse, la plupart des plages étudiées cadrent avec ce modèle bien que le niveau marin soit à la hausse; cependant on doit tenir compte des effets dus à la dominance de la source, du faible niveau d'énergie de la houle, ainsi que des processus initiateurs de la houle transversale.

[Traduit par le journal]
\end{abstract}

\section{INTRODUCT ION}

In recent years two basic types of beaches have been delineated (Kemp 1960, Guza and Inman 1975, Huntley and Bowen 1975, Short 1979, Wright et al. 1979, Bryant 1982). The first type has been labelled dissipative (Wright et al. 1979) because wave energy is largely expended shorewards across a surf zone. The second type has been called reflective because a significant portion of wave energy is reflected from the beach face. This basic classification can be expanded to form a model in which the two extreme beach types can be differentiated from each other with regard to morphology, and wave and current dynamics (Fig. 1). The reflective sand beach is basically a sheltered, accretional, fair-weather beach. It tends to be devoid of inshore morphological expression and has steep foreshore slopes approaching $8^{\circ}$. The dissipative beach is basically an exposed, erosional, storm-dominated beach. It has welldeveloped inshore circulation patterns, multiple bars (or shoals) and flat fore- shores of less than $5^{\circ}$. Between these two extremes lies a continuum of transitional states which shift over time towards one extreme or the other in response to accretion or decreased wave power in the case of more reflective states, and erosion or increased wave power in the case of more dissipative states (Short 1979, Wright et al.1979).

Changes alongshore in sand sediment size and sediment sorting mechanisms also can be incorporated into the model. Observations in the Broken Bay area, Australia (Bryant 1982) revealed the following relationship between beach type and foreshore sediment distribution. Reflective-tending beaches have rapid alongshore change in foreshore grain size (settling velocities $>2.0 \mathrm{~cm} /$ $\mathrm{sec} / \mathrm{km}$ or grain sizes $>0.2 \mathrm{~mm} / \mathrm{km}$ ) and sorting. Dissipative-tending beaches have foreshores with much weaker changes in sediment size alongshore $(<1.2$ $\mathrm{cm} / \mathrm{sec} / \mathrm{km}$ or $<0.1 \mathrm{~mm} / \mathrm{km})$. On reflective foreshores the size of sediment alongshore varies proportionally with wave energy. Longshore components of wave power are also important, but less so than on dissipative foreshores. On steep 
DISSIPATIVE
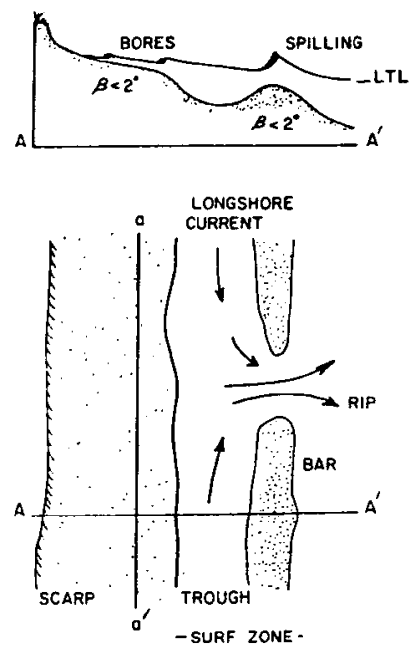

Grain Size

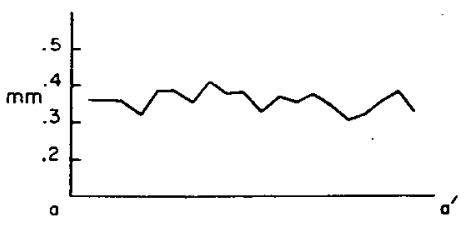

TRANSITION
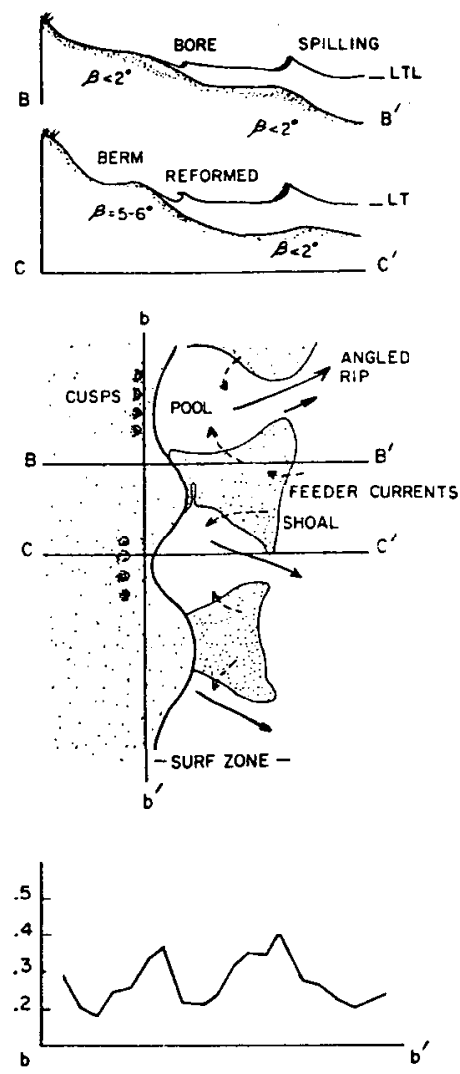

REFLECTIVE
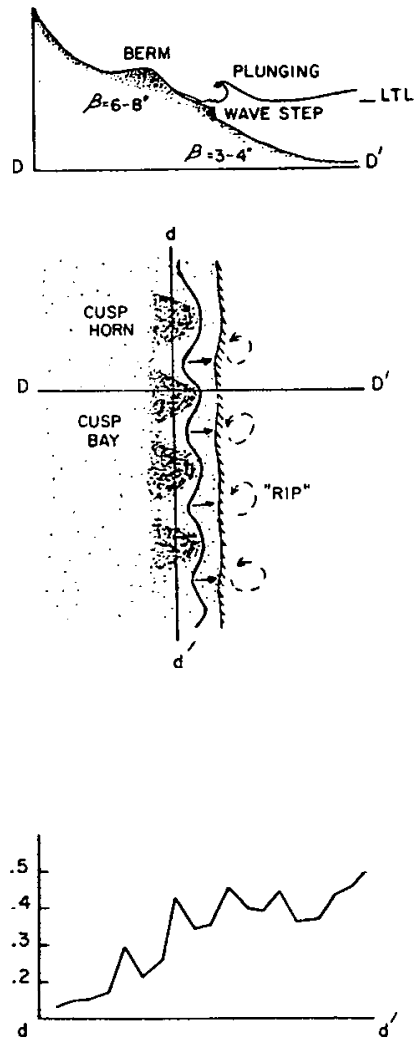

Fig. 1 - Morphology, hydrodynamics and grain size of a) dissipative, b) transitional, and c) reflective beaches

reflective foreshores where backwash is strongest, shear sorting persists and coarse sediment is preferentially concentrated at the low tide mark, where it can be transported alongshore by any alongshore component of the incident wave. Towards the high tide limit where finer sediments are concentrated, longshore transport can only be induced by the zig-zag motion of swash. The latter process is slower than the former so coarse grains outdistance fines downdrift (Komar 1977).

On dissipative beaches the dominance of this process is weakened by four other processes. Firstly, longshore current directions on dissipative beaches are neither steady along the beach nor over time. Current reversals because of changes in deep water wave approach are frequent. Steep foreshore size gradings, even if developed, cannot persist over time. Secondly, as the swash zone is dominated by bores, coarse sediment moves upslope under the flow structure of the bore away from the influence of longshore currents. Here shear sorting in backwash takes second place to suspension transport in the swash bore (Nelson and Miller 1975, James and Brenninkmeyer 1977). Thirdly, the foreshore movement of sediment is also affected by mixing of sediment derived from the surf zone. This latter sediment is suspension dominated and undergoes fining downdrift (Ingle and Schnack 1971, Fox 1978). If such fine sediment moves onshore it obscures any coarsening downdrift produced at the shoreline. Fourthly, localized cellular circulation is operative in the surf zone near rip currents. These currents can oppose the direction of wave approach to the beach and produce coarsening opposite to that predicted from wave dynamics. The above observations imply that reflective and 
dissipative beaches emphasize different modes of sediment transport. The reflective foreshore is dominated by shear sorting in the backwash and hence sediment motion is bedload-dominated. The dissipative foreshore has bore transport, sand fountains under breaking waves in the surf zone, and longshore currents feeding into rips. These mechanisms add a suspension component to sediment transport.

That size gradings on reflective beaches are temporally stable indicates that accretional status and wave power are not the only factors determining beach state compared with those on dissipative foreshores. The permanency of gradings, as well as beach state, directly relate to temporal variation in the angle of wave approach. Because of efficient wave refraction over nearshore bathymetry, waves approaching a beach at the back of a deep re-entrant or embayment are shore-normal regardless of the deep water wave approach. On exposed ocean beaches refraction is not as complete, and inshore wave alignment varies daily or weekly concommitant with the passage of weather systems. This variation in wave approach forms a differentiating mechanism for the two beach types and accounts for differences in hydrodynamic conditions which produce sediment sorting. On dissipative-like beaches, planform must continually adjust at some point to erosion initiated by variation in refracted nearshore wave approach. Eroded foreshore sediment moves offshore into the surf zone where it can be moved alongshore to another part of the beach. Unless all surf zone sediment is moved shoreward under fairweather conditions, the hydrodynamic conditions established in a surf zone, and responsible for weak size gradings alongshore, persist. On more reflective foreshores beach planform has no need for continual adjustment because waves

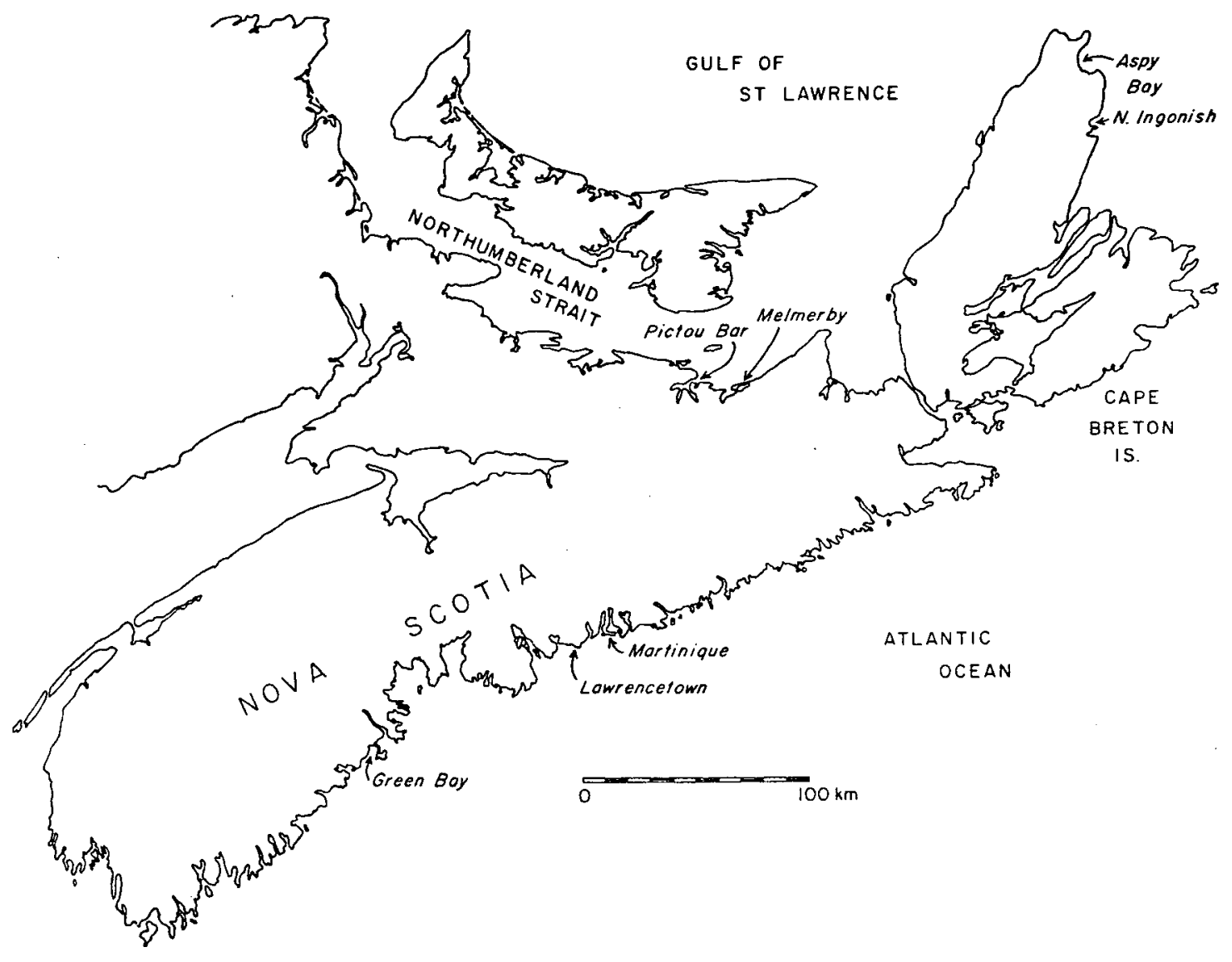

Fig. 2 - Location diagram of foreshores samples in Nova Scotia. 
mainly approach shore-normal types. Sediment accumulation is concentrated on the beach face and resulting hydrodynamic conditions permit steep permanent longshore size gradings.

The most likely morphological state of any beach can be approximated knowing the physiographic setting of that beach, the characteristics of its wave climate, and observations of inshore morphology and variation in that morphology over time. The latter two factors can commonly be determined using air photographs taken over time. The modal positioning of abeach in the morphological spectrum will permit initial prediction of foreshore sediment benaviour which can be further refined by field sampling of sediment alongshore. This approach was applied to a selection of beaches in Nova Scotia (Fig. 2) to assess the applicability of the above model under conditions where there was active sediment source mainly due to headland erosion caused by rising sea level, and where wave energy could be low because of ice-constraint or offshore winds.

\section{BEACH DESCRIPTION}

The beaches used in this study are situated along the Atlantic and Northumberland Strait coastlines of Nova Scotia (Fig. 2). The beaches on the Atlantic mainland coast are exposed to higher wave energy throughout the year because they are ice-free, while beaches on Cape Breton Island and areas adjacent to Northumberland Strait are ice-protected from mid-December up to April. In addition beaches adjacent to Northumberland Strait have restricted fetches which range from $50 \mathrm{~km}$ to a maximum of 300 $\mathrm{km}$, and are developed from northeast waves. While wave periods range from $7.0-14 \mathrm{sec}$ and the heights from 1.0-2.0 $m$ on the Atlantic coast (Keeley 1977), periods and heights rarely exceed 6.0 $\mathrm{sec}$ and $1.5 \mathrm{~m}$ respectively in Northumberland Strait. Wave energy on the Atlantic coast is seasonally greater in winter and beaches experience winter erosion and summer accretion (Owens and Bowen 1977). In Northumberland Strait this seasonal change is negated by winter ice which protects beach foreshores during winter and spring storms. Beaches in this Strait respond daily or weekly in the ice-free season to extra-tropical storms and changes in wave direction brought about by the passage of anticyclones (Owens 1977). Tides along the Atlantic and Northumberland Strait vary from $1.4 \mathrm{~m}$ at Martinique to $0.9 \mathrm{~m}$ at Ingonish and $1.0 \mathrm{~m}$ at Pictou. All areas are subject to rates of sea level rise of $30 \mathrm{~cm} / 100 \mathrm{yr}$ (Grant 1970). This rapid rise in sea level has led to the landward retreat of beaches and the continual supply of sediment from eroded adjacent coastline. For the beaches along the Atlantic mainland coast of Nova Scotia, this sediment is derived from gravelly-boulder till; in northeastern Cape Breton Island it is derived from glacial outwash and Mississippian sandstones; and along Northumberland Strait, from glacial till and poorly lithified Permian sandstone. Because rates of sediment supply are not substantial and because many beaches, especially in Northumberland Strait, are semi-compartmentalized, beach progradation is not prevalent. However, local sediment sources are sufficiently active to affect nearby foreshore sediment characteristics.

\section{SEDIMENT SAMPLING AND ANALYSIS}

All beaches were sampled in the late autumn of 1977 when the effect of ice was minimal. Surface lamina samples were collected at $60 \mathrm{~m}$ intervals at the midforeshore location on a falling tide. This location and timing ensured that no actively transported sediment in swash or backwash was sampled. Any differences between samples due to instantaneous current velocity levels in the swash were thus minimized. Two grams only were collected at each location. Testing elsewhere on foreshores (Bryant 1977) has shown that these low sample weights, when analyzed, are representative of mean and standard deviation of settling velocity distributions within a 5-m distance of each sample point. The low weight also minimized wall ef- 
fects in settling tube analysis. All samples $(n=255)$ were analyzed in a 200 $\mathrm{cm}$ long, $12-\mathrm{cm}$ wide settling tube which used weight frequency as a basis of measurement. Size in the study was measured using settling velocity expressed by $\mathrm{cm} / \mathrm{sec}$. A table of conversion to $\phi$ units and $\mathrm{mm}$ is presented in Table 1 . Results using settling tubes show less multimodality and appear to represent the hydraulic properties of sand better than sieving analysis (Reed et al. 1975, Bryant 1977). Output from the tube in the form of cumulative weight was recorded on a chart, then digitized and the results were used to calculate moment
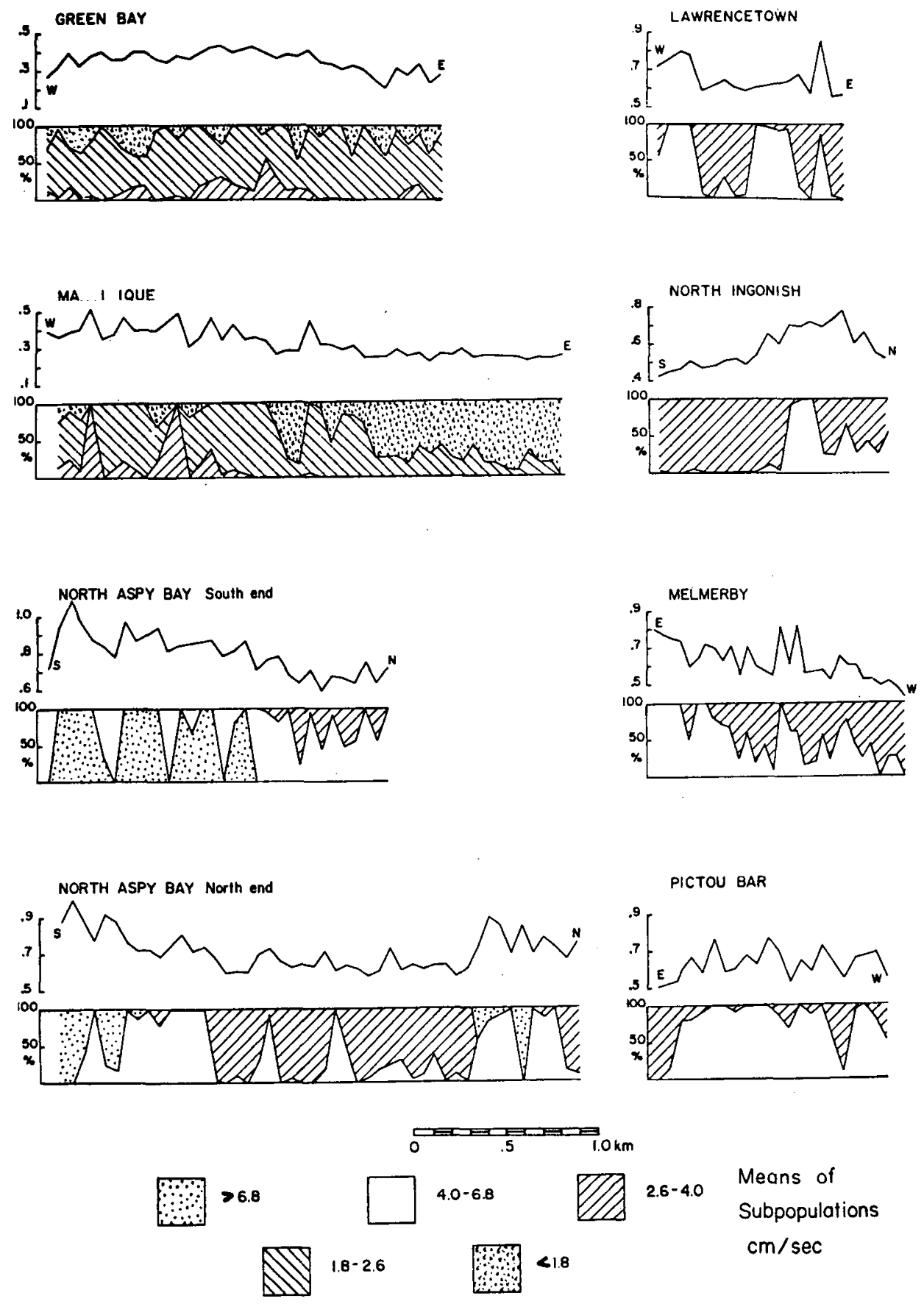

Fig. 3 - Grain settling velocity trends longshore and percentage of each sub-population identified for Nova Scotia beaches. For presentation purposes, settling velocity values are $\log _{10} \mathrm{~cm} / \mathrm{sec}$. 
means and cumulative probability plots. Longshore variation in mean settling velocity is plotted for each beach in Figure 3 while probability plots are shown in Figure 4.

\section{DESCRIPTION OF RESULTS}

\section{a) Green Bay}

Green Bay is a flat sloped ( 2 degrees), fully compartmentalized beach of low energy, exposed only to south-approaching waves (Fig. 5). The inshore is planar without bars or rip channels. There appears to be no substantial active sediment source and most of the foreshore is undergoing landward retreat. Waves at the time of sampling had a period of $10.2 \mathrm{sec}$ and broke at shore with heights of $40 \mathrm{~cm}$ at the west end, $50-75 \mathrm{~cm}$ in the middle, and $20 \mathrm{~cm}$ at the sheltered eastern end. Most wave energy was dissipated across the lower foreshore. Despite the limited fetches available to this beach and lack of inshore topography, the foreshore can be considered dissipative because of the low slope and energy dispersal across the lower beach face. Wave energy is commonly so low that set-up and subsequent current generation and sediment entrainment necessary for bar formation is not possible. Longshore variation in mean settling velocity agrees with this morphological classification. Highest values correspond to areas with greatest breaker height, and gradings are less than $1.2 \mathrm{~cm} / \mathrm{sec} / \mathrm{km}$ except at the she1tered eastern end.

\section{b) Lawrencetown}

Lawrencetown is a higher-angled beach (3-6 degrees), semi-compartmentalized, and exposed to southeast waves. The beach is actively being supplied with
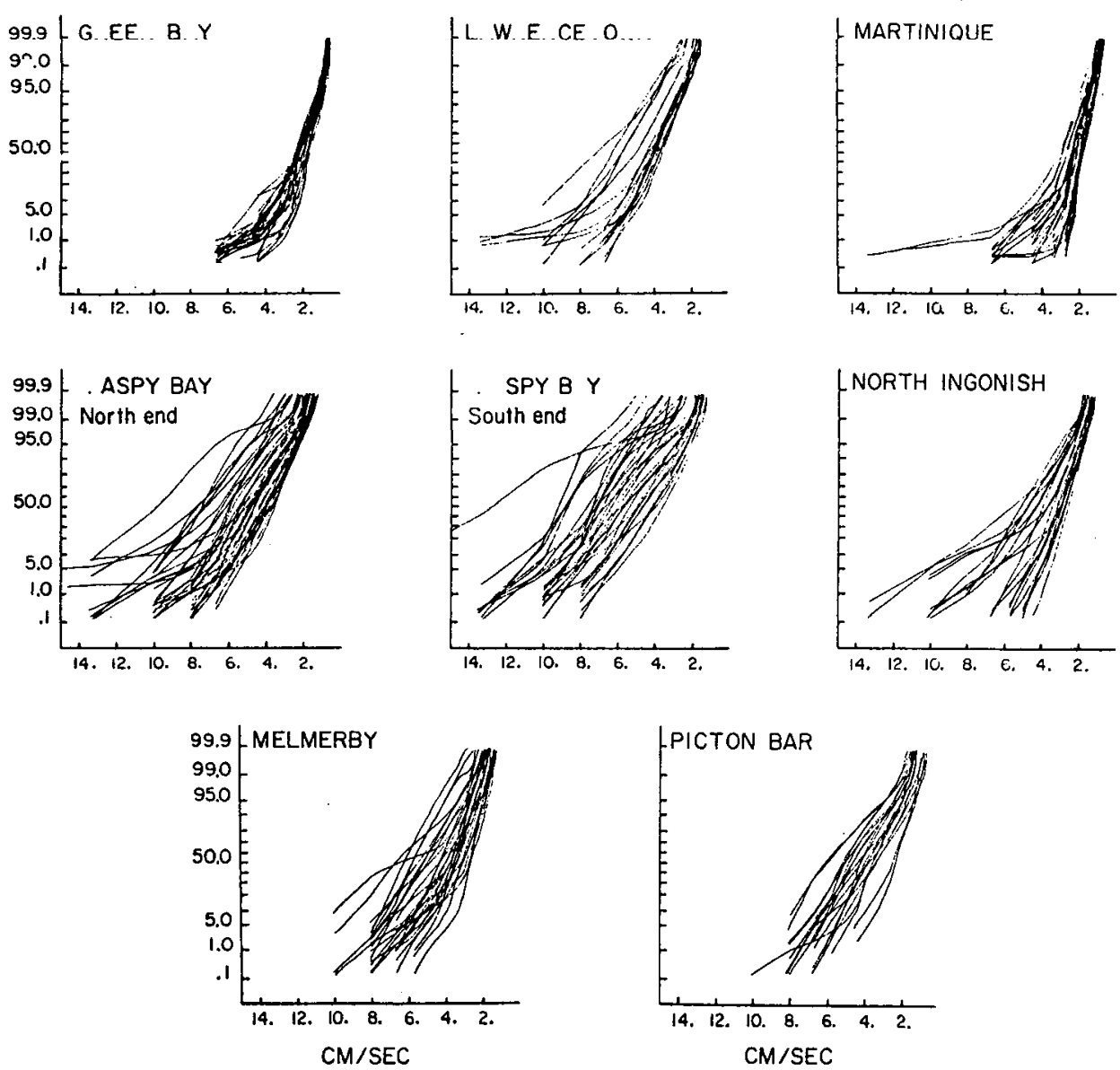

Fig. 4 - Representative cumulative settling velocity curves for each beach sampled. 
Table 1

CONVERSION TABLE OF SETTLING VELOCITY TO GRAIN SIZE

Settling velocity

$\mathrm{cm} / \mathrm{sec}$

1.0

2.0

3.0

4.0

5.0

6.0

7.0

8.0

9.0

10.0

11.0

12.0

cobble and sand from wave-eroding drumlin headlands at both ends. The foreshore has developed a shore normal segregation of cobble and sand (Fig. 6). The cobbles, which increase in amount eastwards, are found at the back of the beach as a storm-wave ramp, on cusp horns or at the low-tide mark. The foreshore is sand-starved as most sand is recirculated within an active surf zone. Wave period at the time of sampling averaged 10.0 sec with waves breaking at $0.5 \mathrm{~m}$ heights over rhythmic topography consisting of alternating rip channels and shore-tied shoals. The beach can be considered transitional, tending towards more dissipative conditions at low-tide when waves break and loose energy across the surf zone. Longshore sediment size variation supports this classification as the trend is weak and highly variable.

c) Martinique

Martinique is a low angle ( $<3$ degrees), fully compartmentalized beach exposed to southwest to southeast waves. The beach is actively eroding landward and is being supplied from both ends with sand sediment derived from till headlands. Some deposition of cobble material originating from these tills occurs at the high tide limit. The beach has a we11-developed surf zone with comple-

\begin{tabular}{lc}
\multicolumn{2}{c}{ Grain size } \\
phi units \\
.116 & 3.11 \\
.179 & 2.48 \\
.236 & 2.08 \\
.293 & 1.77 \\
.349 & 1.52 \\
.406 & 1.30 \\
.463 & 1.11 \\
.522 & 0.94 \\
.583 & 0.78 \\
.644 & 0.63 \\
.708 & 0.50 \\
.772 & 0.37
\end{tabular}

mentary cellular circulation (Keeley and Bowen 1977). During sampling, $12 \mathrm{sec}$ waves broke at $20-30 \mathrm{~cm}$ heights at the more sheltered eastern end, and at 50 $\mathrm{cm}$ elsewhere, to form a surf zone 50-70 $m$ wide. The beach can be classified as dissipative, rarely without an active surf zone. Sediment size measured by Keeley (1977) over 18-months shows temporal and seasonal variation characteristic of a dissipative foreshore. The autumn sampling in the present study agrees with these observations with a weak grading $(0.4 \mathrm{~cm} / \mathrm{sec} / \mathrm{km})$ decreasing towards the sheltered end of the beach.

\section{d) North Ingonish}

North Ingonish is a medium-sloped (4-5 degrees), fully compartmentalized beach exposed to easterly approaching storm waves of the North Atlantic, and constrained in winter by ice for up to four months. The beach is undergoing landward retreat and a coarse boulder till is being eroded along the northern headland. For most of the year offshore winds reduce wave energy to the extent that waves only break at shore without moving sediment within a surf zone. On the day of sampling, wave period aver-aged $10 \mathrm{sec}$ with $0.3 \mathrm{~m}$ waves surging evenly up the beach face. A distinct single, cuspate storm bar is present on 


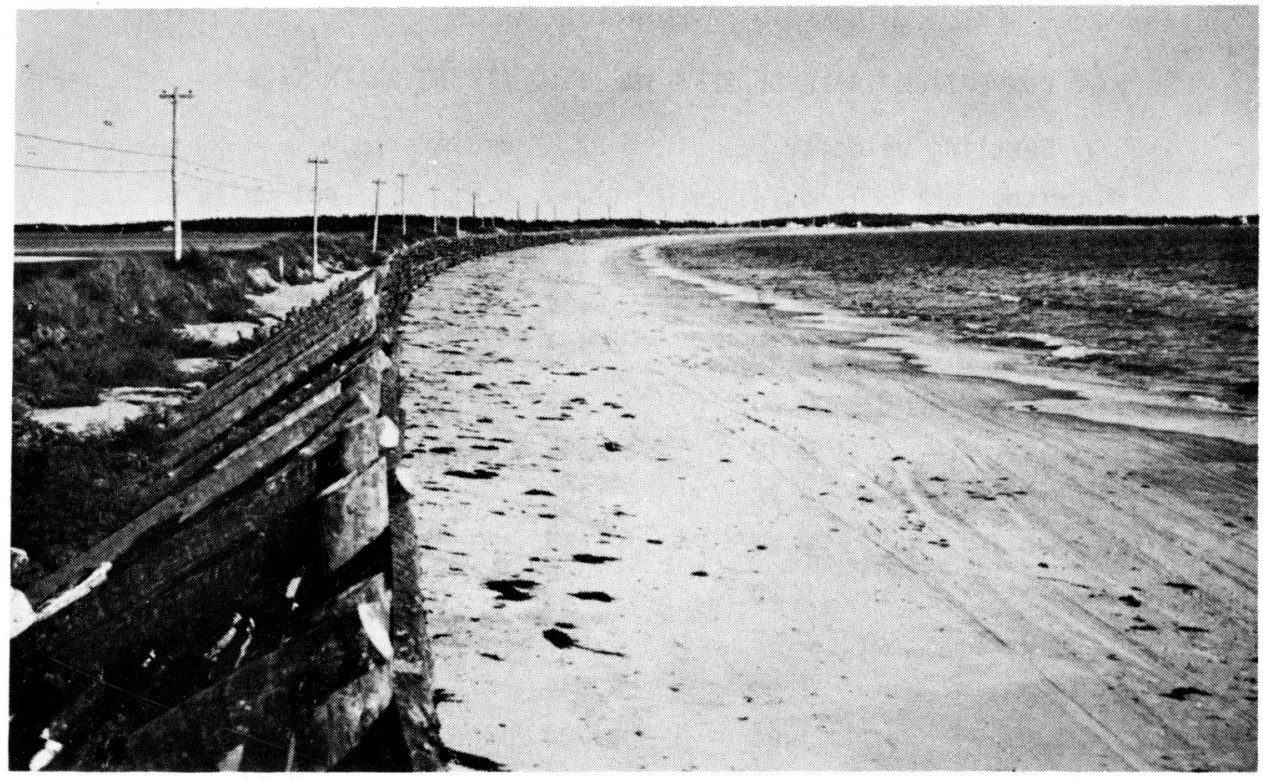

Fig. 5 - Green Bay foreshore.

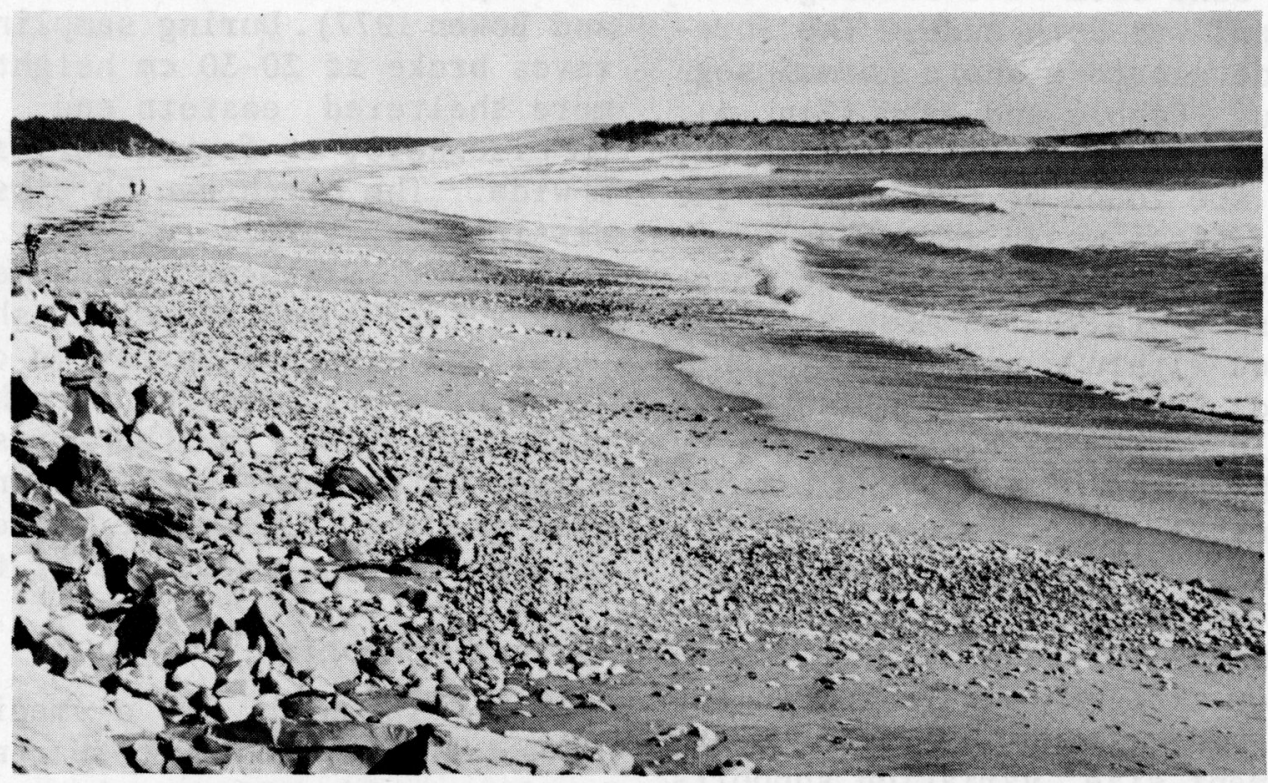

Fig. 6 - Lawrencetown foreshore.

air photographs (Fig. 7) 200-m from shore. The beach can be considered fully reflective under fair-weather conditions but becomes dissipative under periodic high energy storms. Only the southern $1500-\mathrm{m}$ of the beach was sampled because of the presence of poorly sorted sand and gravel sediment northwards. The settling velocity grading is characteristic of a reflective foreshore with a gradient both exceeding $2.2 \mathrm{~cm} / \mathrm{sec} / \mathrm{km}$ and increasing towards the higher energy part of the beach.

\section{e) North Aspy Bay}

Aspy Bay beach consists of two sand barriers at the head of Aspy Bay, which is a fault-controlled, compartmentalized embayment facing to the northeast. The northern beach was surveyed north and south of a central inlet. Both parts are similar with steep foreshores (up to 8 


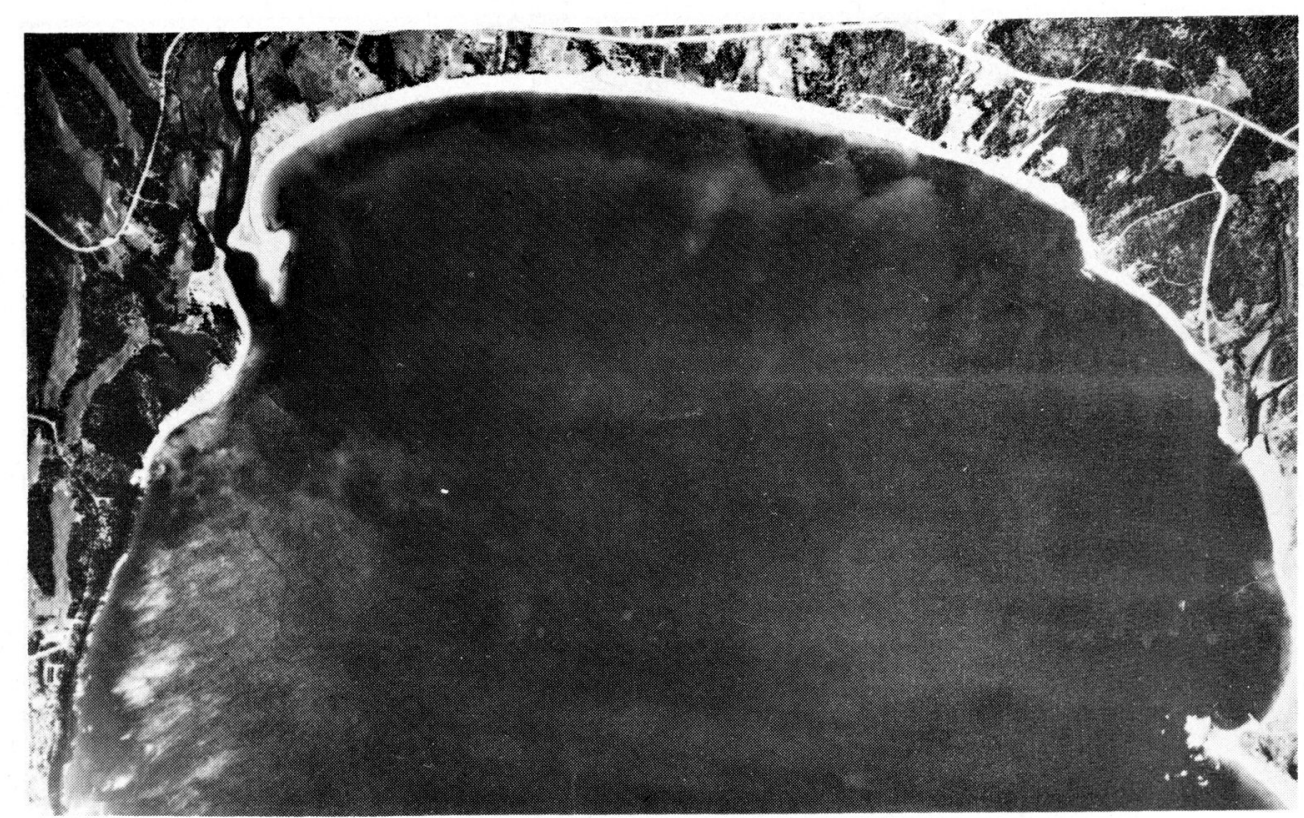

Fig. 7 - North Ingonish (Canadian Government Photo A19793-149)

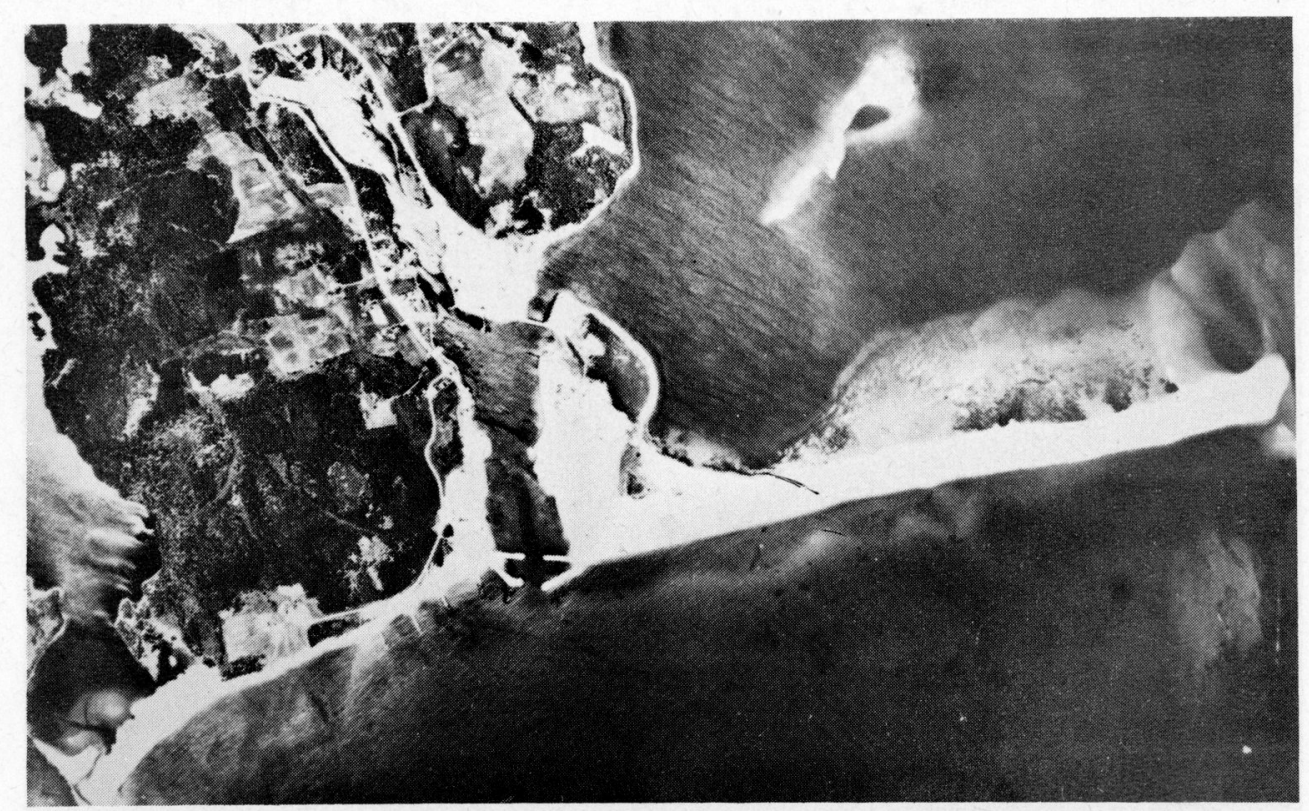

Fig. 8 - North Aspy Bay, south end (Canadian Government Photo A19517-31). Note cuspate storm bar.

degrees). Noticeable cobble, originating from bedrock in the adjacent nearshore zone, is present around the inlet. Wave and ice conditions are similar to North Ingonish and at the time of sampling $0.25-\mathrm{m}$ high waves broke at shore with a period averaging only $5 \mathrm{sec}$. Energy decreases northward because of the sheltering effect of the northern headland. Both ends of the beach have outwash and bedrock undergoing active erosion. Air photographs (Figs. 8, 9) again illustrate a single shore-parallel. storm bar which becomes cuspate towards the south end. Storms modify the foreshore as seen by the overwashes penetrating the backing dune. The beach can be classified as fully reflective under fair-weather conditions, but dissipative during high energy storms. Foreshore settling velo- 


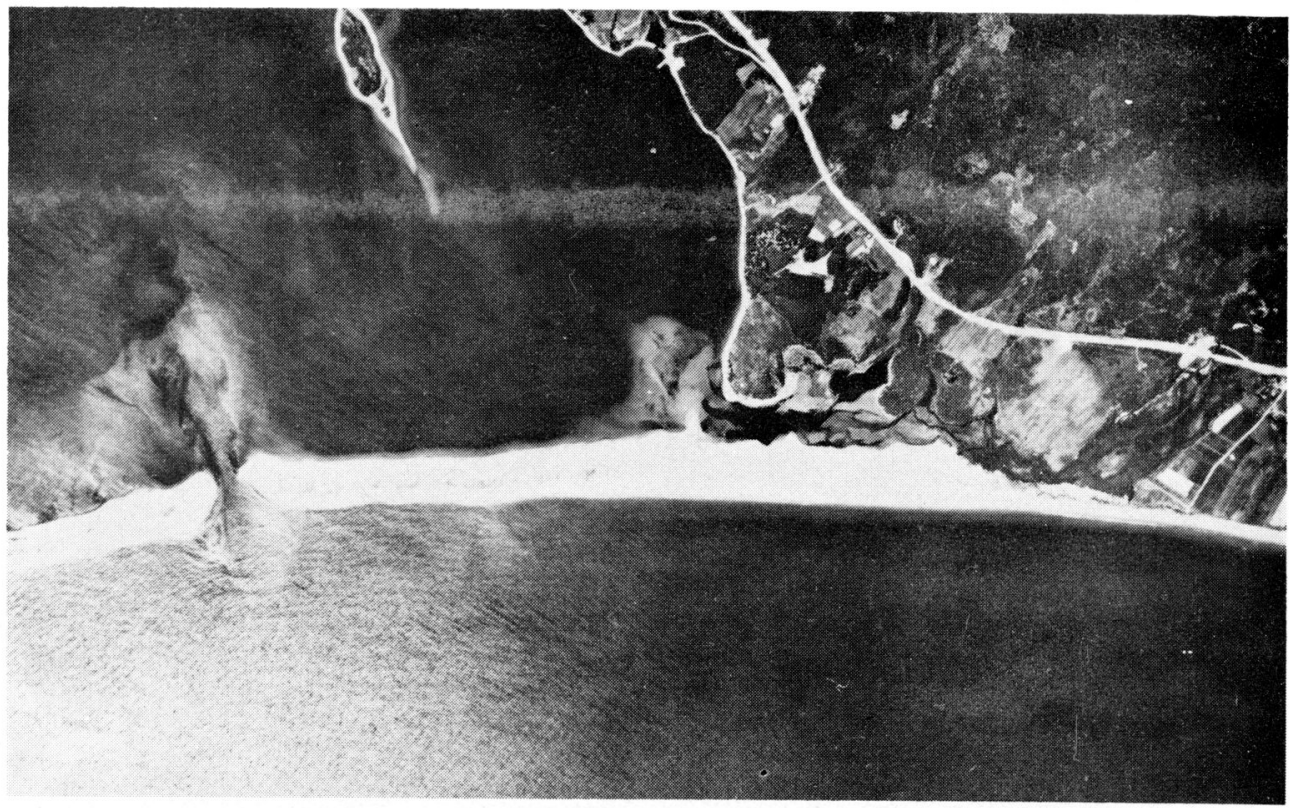

Fig. 9 - North Aspy Bay, north end (Canadian Government Photo A19517-2)

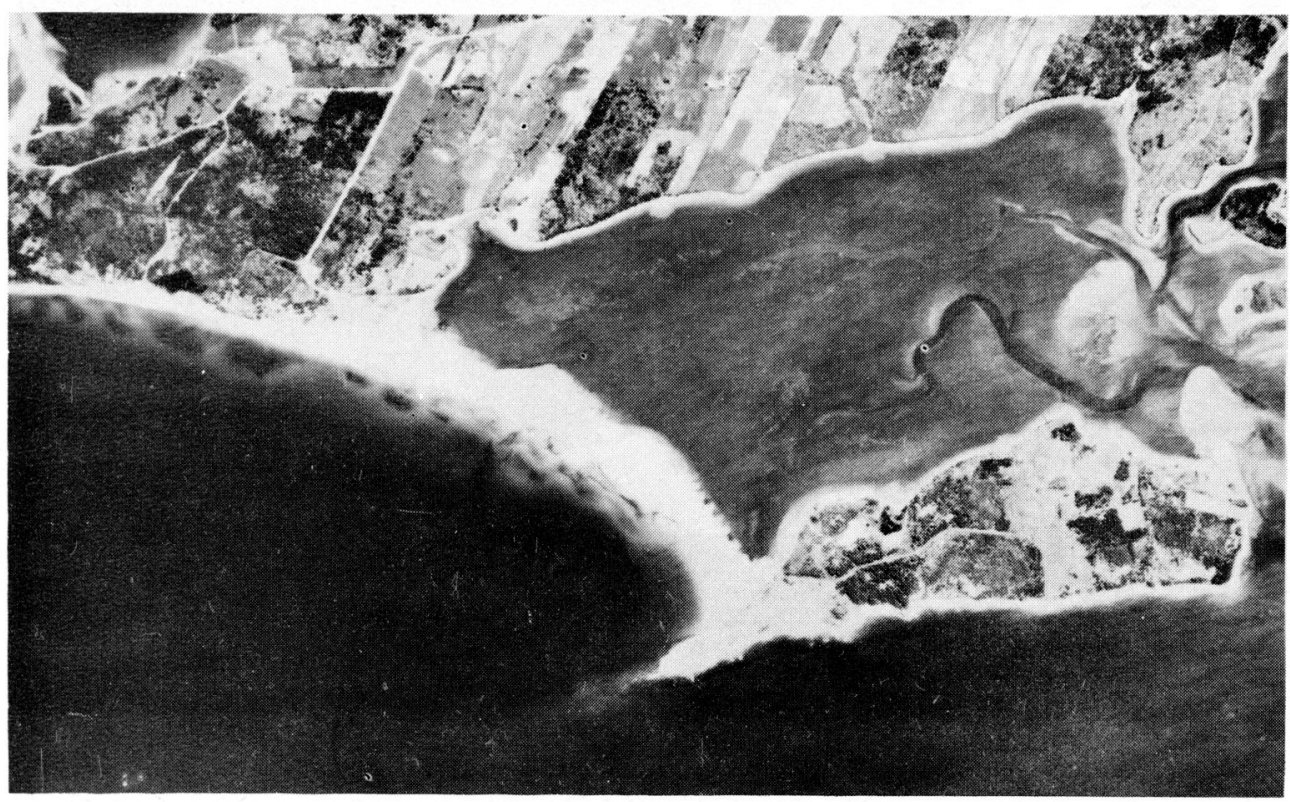

Fig. 10 - Melmerby (Canadian Government Photo A21416-94)

city gradings alongshore do not fit this classification consistently. At the southern end, settling velocities decrease towards the inlet at a rate characteristic of reflective foreshores (2.0 $\mathrm{cm} / \mathrm{sec} / \mathrm{km})$. Highest velocities occur at highest wave energies. On the northern segment grain settling velocity increases towards the inlet and adjacent to eroding outwash deposits at the northern end. Rates of change are less than those found on reflective foreshores. Superimposed on these trends, especially at the south end of the beach and north of the inlet, is a pronounced oscillation having a wave length of $350 \mathrm{~m}$ and an amplitude of $1.2 \mathrm{~cm} / \mathrm{sec}$. This regular pattern has been related elsewhere to the presence of edge waves (Bryant 1979). The higher values north of the inlet 
and at the northern end are anomolous for this type of beach.

\section{f) Melmerby}

Melberby is a flat ( $<3$ degrees) lowenergy, weakly compartmentalized beach exposed to a $50 \mathrm{~km}$ wide northeast fetchwindow extending up to $300 \mathrm{~km}$ into the Gulf of St. Lawrence. Northeast waves generate a strong westerly. longshore drift, which is reversed by much smaller waves originating from fetches of less than $50 \mathrm{~km}$ to the west. The fact that the beach is icebound for 4-5 months of the year, mainly when wave energy should be maximum, great $1 y$ decreases the potential for change on this beach. Me1merby is characteristic of more dissipative beaches with a surf zone up to $70 \mathrm{~m}$ wide dominated by cuspate bars with intervening rip channels (Fig. 10). The beach has been extensively mined (MacGregor 1978) and is retreating 1 andward. Erosion of till cliffs at both ends of the beach is supplying small amounts of sand to the surf zone. Residual longshore drift appears to be westward with coarser sand being added to the eastern end of the beach. At the time of sampling, wave period was only $5.5 . \mathrm{sec}$ with wave height less than 10 $\mathrm{cm}$. The mean settling velocity trend is characteristic of neither a dissipative nor a reflective foreshore (Fig. 4). Firstly, the trend is as steep as those normally found on reflective foreshores $(2.3 \mathrm{~cm} / \mathrm{sec} / \mathrm{km})$ although there is some variation. Secondly, the sands fine downdrift - a fact not substantiated for reflective type foreshores. Thirdly, the trend is steep even though longshore variation in wave energy is minimal.

\section{g) Pictou Bar}

Pictou Bar occupies a similar setting as Melmerby except that exposure to wave energy is much diminished. Because the beach is recessed into an embayment such that variation in wave direction is minimized, the beach foreshore has taken on reflective attributes. Foreshore slope increases towards the exposed western end (up to 5 degrees). At the time of sampling wave period was 3-4 sec with waves breaking $20-30 \mathrm{~cm}$ at shore. Some sediment is being added to the beach from the erosion of friable bedrock cliffs to the east. The beach is also ice-locked up to five months of the year, and ice-push of sediment across the inshore onto the foreshore has been observed in spring. The beach is protected by a storm bar which approaches shore towards the inlet end (Fig. 11) where strong flood tidal currents were observed in the trough. The

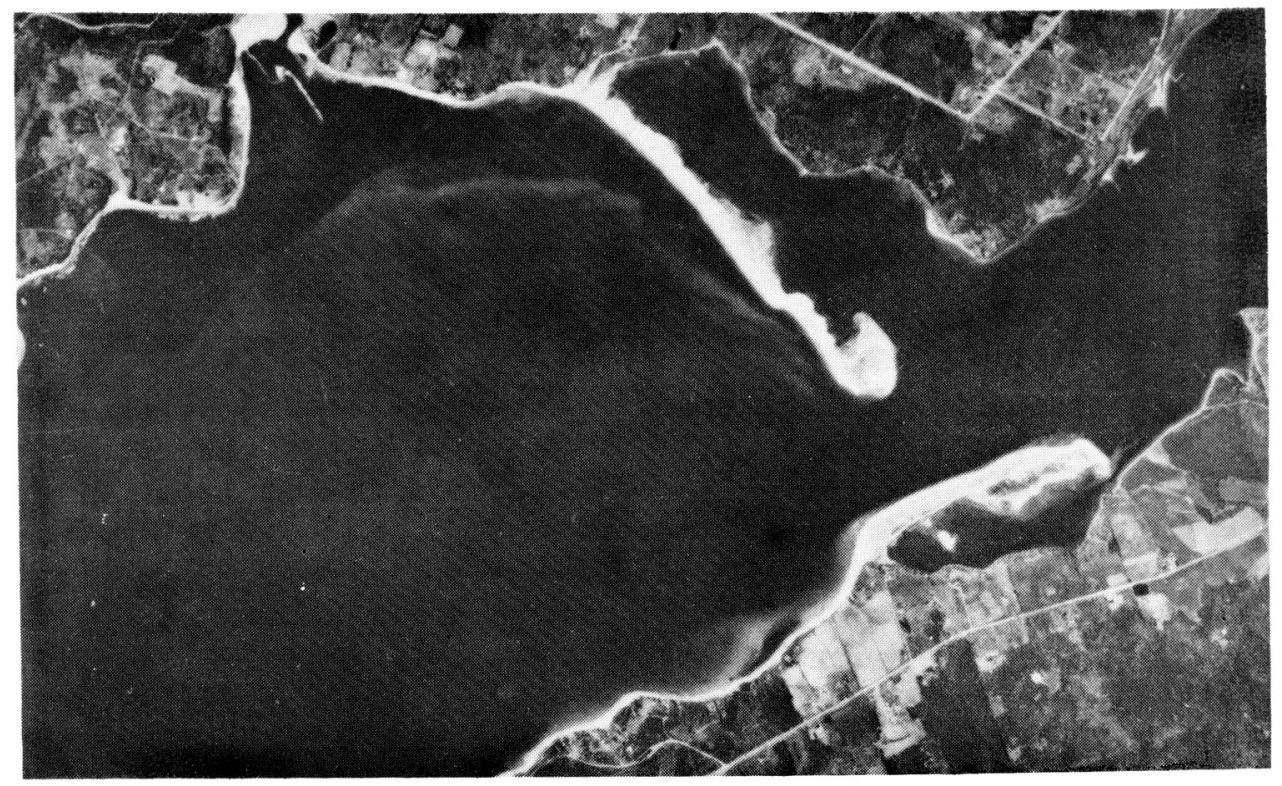

Fig. 11 - Pictou Bar (Canadian Government Photo A21426-26) 
Table 2

SUMMARY OF MORPHOLOGY AND SEDIMENT CHARACTERISTICS OF SOME NOVA SCOTIAN BEACHES

\begin{tabular}{|c|c|c|c|c|c|}
\hline Beach & $\begin{array}{l}\text { Deduced } \\
\text { Morphological } \\
\text { Classification }\end{array}$ & $\begin{array}{l}\text { Settling } \\
\text { Velocity } \\
\text { Grading }\end{array}$ & $\begin{array}{c}\text { Grading } \\
\text { Supports } \\
\text { Norphologic } \\
\text { Classification }\end{array}$ & $\begin{array}{l}\text { Field } \\
\text { Evidence } \\
\text { of Active } \\
\text { Sediment } \\
\text { Input }\end{array}$ & $\begin{array}{l}\text { Settling } \\
\text { Velocity } \\
\text { Sub-populations } \\
\text { Indicate } \\
\text { Source }\end{array}$ \\
\hline Green Bay & Dissipative & $<1.2 \mathrm{~cm} / \mathrm{sec}$ & Yes & No & - \\
\hline Lawrencetown & Dissiptaive & 0.0 & Yes & Yes & - \\
\hline Martinique & Dissipative & $0.4 \mathrm{~cm} / \mathrm{sec}$ & Yes & Yes & - \\
\hline N. Ingonish & Reflective & $>2.2 \mathrm{~cm} / \mathrm{sec}$ & Yes & Yes & - \\
\hline $\begin{array}{l}\text { Aspy Bay } \\
\text { South End }\end{array}$ & Reflective & $2.0 \mathrm{~cm} / \mathrm{sec}$ & Yes & Yes & - \\
\hline $\begin{array}{l}\text { Aspy Bay } \\
\text { North End }\end{array}$ & Reflective & $1.6 \mathrm{~cm} / \mathrm{sec}$ & No & Yes & Yes \\
\hline Melmerby & Dissipative & $2.3 \mathrm{~cm} / \mathrm{sec}$ & No & Yes & Yes \\
\hline Pictou Bar & Reflective & 0.0 & No & Yes & Yes \\
\hline
\end{tabular}

bar may be partially controlled in form and location by these currents. Settling velocity gradings bear no resemblance to a reflective foreshore. Grading is non-existent with a regularly spaced, strongly apparent, $300 \mathrm{~m}$ periodicity superimposed alongshore. The latter possibly reflects the presence of standing edge waves which can easily be generated within an embayment of this shape.

\section{DISCUSSION}

The observations presented are tabulated in Table 2. Of the 8 beaches or segments studied, 5 have foreshore sediment characteristics which support the cateloguing of those beaches within the reflective-dissipative model based upon physiographic setting, and wave and morphology observations. It was suspected that the anomalous gradings were due to source dominance. This was investigated by assuming that a source area should be supplying sediment to a beach with settling velocity characteristics slightly different from the overall beach composition. Thus individual settling velocity distributions would consist of sub-populations, one of which would reflect the source area and would increase in relative amount towards this area. It was further assumed that these sub-populations were normally distributed and could be separated by a curve dissection technique. The various techniques for doing this have been reviewed by Clarke (1976) and can be divided into graphical or numerical methods.

The graphical measures are subjective and tedious to use, while the numerical techniques are more objective and efficient, and so were used here. These techniques are based on either maximum likelihood or non-linear least squares methods. In the present study a nonlinear least squares approach developed by Clarke (1977) was used to segment cumulative curves into sub-populations. The program has the advantage of using group endpoints with either uniform or non-uniform class intervals. Up to five sub-populations can be delineated. The program requires as input an approximation to the mean, standard deviation and proportion of each sub-population which could be estimated from cumulative probability plots. The solutions were tested statistically by recombining the calculated sub-populations and comparing this distribution to the original one using the Kolmogorov Smirnov test. 
It is important to note that the means of sub-populations reported in this study do not represent cut-off values of truncated sub-populations, but rather the mean settling velocity of a subpopulation which may overlap with other sub-populations. Over $90 \%$ of all distributions in the study could be dissected into two or three normal subpopulations. The remaining distributions usually were uni-modal and normally distributed to being with. All sub-populations when recombined were similar to the original distribution at the 0.05 level of significance with maximum deviation between the two curves being less than $2 \%$.

The percent frequencies of sub-populations found along each beach are plotted in Figure 3. These sub-populations are inferred as representing characteristics of a sediment source. The grouping of the means of these sub-populations into categories has been done for plotting purposes and does not imply any similarity between beaches. In many cases the delineation of sub-populations reinforced an already explained sediment pattern. For instance, the coarsest subpopulation is prominant at the higher wave energy portion of the foreshore where mean grain size is coarsest on Green Bay. The coarsest sub-population is also dominant adjacent to high tide cobble deposits on Lawrencetown and at points of greatest settling velocity on the regular longshore oscillations on the south end of Aspy Bay. The latter observation agrees well with the sorting mechanisms postulated for edge wave generated patterns (Bryant 1979).

On the beaches with anomalous sediment patterns coarse sub-population proportions are indicative of source. On the north end of Aspy Bay the coarsest sub-population appears adjacent to an eroding till cliff and abruptly disappears when the cliff terminates. A second area near the inlet with the coarsest sub-population lies adjacent to an inshore area marked on bathymetric charts as bedrock. On Melmerby the coarsest sub-population accounts for $100 \%$ of sands at the east end where coarser till is being eroded. This sub-population decreases in frequency to $0 \%$ downdrift towards the western end. On Pictou Bar finest sediment is most frequent towards the sheltered eastern end where active cliffline erosion is occurring. The active addition of sediment on these beaches masks the gradings which would be expected given their respective settings and physical characteristics.

\section{CONCLUSIONS}

Generally the observed morphology, and wave and current characteristics permit a beach to be classified as fully reflective or as some state leading towards total dissipation. Short (1979) and Wright et al. (1979) outline some transitional morphology which can be used to define the degree of dissipation. Within this model the following observations can be made about foreshore size gradings (Bryant 1982).

1) On fully reflective foreshores gradings are steep $(>2.0 \mathrm{~cm} / \mathrm{sec} / \mathrm{km}$ or $0.2 \mathrm{~mm} / \mathrm{km}$ ) and temporally stable. This grading type should only be found on beaches which have no inshore morphological variation or surf zone (Fig. 1c).

2) On fully dissipative foreshores, gradings are weaker $(<1.2 \mathrm{~cm} / \mathrm{sec} / \mathrm{km}$ or $0.1 \mathrm{~mm} / \mathrm{km}$ ) and temporally unstable. Fully reflective beaches do not have these characteristics (Fig. 1a).

3) On transitional beaches with well developed cuspate bar and rip channel systems close to shore, size gradings are still temporally unstable, however grain size values increase back of rip channels (Fig. 1b).

While the difference between reflective and dissipative ends of the morphological spectrum has been attributed to wave power or the degree of accretion and erosion (Short 1979, Wright et al. 1979), the stability of gradings can be attributed to differences in refracted swell characteristics between these two beach extremes. Refracted swell on reflective beaches has little directional variation, while that on dissipative beaches responds to daily or weekly fluctuations in the direction of wave approach. The mechanism linking dissipa- 
tive beach conditions to varying wave directions lies in the need for continual re-alignment of beach planform to the incoming wave front. If planform is not in adjustment the beach face is locally eroded and sediment moves offshore into the surf zone. This sediment can then be moved efficiently by longshore currents until it is deposited at a beach boundary or point where wave approach is shore-normal. The greater the variation in wave direction, the larger the amount of sand tied up in the surf zone. Moreover, the greater the wave energy the larger the surf zone, and the greater the width of bars or shoals over which wave attenuation occurs. The associated hydrodynamics produce weak gradings which develop to vary over time.

Distributions of sediment on Nova Scotian beaches, reported here, support the general characteristics of the reflective-dissipative mode1, but also point to the following additional factors. Firstly, if a beach has the morphology and hydrodynamics of a reflective beach but the foreshore grading decreases as wave energy increases, or if a beach has an active surf zone with barred topography but the foreshore grading is steep (approximately 2.0 $\mathrm{cm} / \mathrm{sec} / \mathrm{km}$ ), active source dominance may be suspected. In the present study, active erosion of till and friable bedrock cliffs was responsible for altering foreshore gradings. The continuing rise in sea-level along much of the Maritime coastline must be considered as a mechanism actively providing sediment to many beaches.

Secondly, if wave energy is very low and beaches occupy sheltered locations devoid of inshore morphology, gradings need not indicate reflective beach conditions. Low wave energy cannot efficiently sort sediment both onshore and longshore. In addition wave action cannot move sediment up the beach face, so the beach face is flat and accentuates wave energy dissipation especially in the lower intertidal zone. In these conditions, foreshore sediment gradings may be dissipative $(<1.2 \mathrm{~cm} / \mathrm{sec} / \mathrm{km})$.
Wave energy is so low that the inshore circulation and morphology associated with dissipativeness cannot be generated. Green Bay exemplifies this condition.

Thirdly, beaches with well defined, single, shore-parallel or cuspate bars may not necessarily have foreshore characteristics that can be considered dissipative. The bars may form under high energy conditions with offshore movement of sediment. Under fair-weather conditions this sediment would normally migrate through a surf zone back onto the peach face; however if modal wave energy regime is low, the bars may be below wave-base and during fair-weather remain inactive until the next infrequent storm. The bars along Ingonish, Aspy Bay and Pictou Bar, are of this type. Such inactivity may be induced during winter and spring storms by the protective influence of ice.

Fourthly, regularly-spaced oscillations may appear in settling velocity gradings alongshore. These usually are associated with alternative bars and channels in transitional beach states; however they can appear on reflective foreshores without barred topography. The peak of these oscillations contains a higher proportion of coarse sediment which is indicative of a longshore sorting process triggered by standing edge waves at the beach face, within a surf zone, or within the confines of a deep narrow embayment.

The determination of size gradings on a foreshore is important because size gradings intrinsically relate to that beach's morphology and hydrodynamics. Similarly morphologic identification alludes to specific types of gradings and sorting processes. The general mode1 relating morphology, hydrodynamics and sediment characteristics was applicable to Nova Scotian beaches; but the model must be expanded to include low energy and source dominance. Very low energy dissipation on the lower foreshore of beaches here can become a determining variable of the model. In addition bars may not indicate more dissipative conditions; but simply that infrequent storm events occur on a nor- 
mally reflective-type beach. Low energy conditions in Nova Scotia can be enhanced by offshore winds in the fairweather season or by inshore ice during the storm season. The possibility of source dominance altering gradings predicted by the model is enhanced in any area where sea level rise is still occurring and causing shoreline erosion.

\section{ACKNOWLEDGEMENTS}

Field work was completed under a postdoctoral fellowship at Bedford Institute of Oceanography. Peter Rosen and Bill Cooper assisted with data collection. Robyn Schweers aided with the production of the plates. Drs. Brian Jones and Gerald Nanson critically read the manuscript. The aerial photographs in Figures 7-9 are copyrighted 1966 and those in Figures $10-11$ are copyrighted 1970 by Her Majesty the Queen in Right of Canada, reproduced with permission of Energy Mines and Resources Canada.

BRYANT, E.A. 1977. Relationships between foreshore sediment sett1ing velocity and breaker wave hydrodynamics, eastern Australian beaches. Unpublished Ph.D. thesis, MacQuarie University, 254p.

BRYANT, E.A. 1979. Edge wave and sediment sorting relationships on beach foreshores, Broken Bay. Search, 10, pp. 442-444.

BRYANT, E.A. 1982. Behaviour of grain size characteristics on reflective and dissipative foreshores, Broken Bay, Australia. Journal of Sedimentary Petrology, 52, pp. 431-450.

CLARK, I. 1977. ROKE a computer program for nonlinear (least-squares) decomposition of mixtures of distributions. Computer and Geology Science, 3, pp. 245-256.

CLARK, M.W. 1976. Some methods for statistical analysis of multimodal distributions and their application to grain-size data. Mathematical Geology, 3, pp. 267282.
FoX, H.R. 1978. Aspects of beach sand movement on a part of the Lincolnshire coast: a review of some results from recent tracer experiments. East Mediterranean Geographer, 7, pp. 64-72.

GRANT, D.R. 1970. Recent coastal submergence of the Maritime Provinces of Canada. Canadian Journal of Earth Sciences, 7, pp. 676-689.

GUZA, R.T. and INMAN, D.L. 1975. Edge waves and beach cusps. Journal of Geophysical Research, 80 , pp. 2997-3012.

HUNTLEY, D.A. and BOWEN, A.J. 1975. Comparison of the hydrodynamics of steep and shallow beaches. In Nearshore sediment dynamics and sedimentation. Edited by J.R. Hails and A. Carr. Wiley and Sons, London, pp. 69-10.

INGLE, J.C. and SCHNACK, E.J. 1971. Sorting in the surf zone: new evidence from fluorescent tracer studies. Abstracts of the 8th International Sedimentology Congress, Heidelburg, pp. 47.

JAMES, C.P. and BRENNINKMEYER, B.M. 1977. Sediment entrainment within cores and backwash. Geoscience and Man, 18, pp. 61-68.

KEELEY, J.R. and BOWEN, A.J. 1977. Longshore variation in longshore currents. Canadian Journal of Earth Sciences, 14, PP. 1897-1905.

KEELEY, J.R. 1977. Nearshore currents and beach topography, Martinique beach, Nova Scotia. Canadian Journal of Earth Sciences, 14, pp. 1906-1915.

KEMP, P.H. 1960. The relationship between wave action and beach profile characteristics. Proceedings of the 7 th Conference of Coastal Engineering, 1, pp. 262-277.

KOMAR, P.D. 1977. Selective longshore transport rates of different grain-size fractions within a beach. Journal of Sedimentary Petrology, 47, pp. 1444-1453. 
MacGREGOR, C.D.R. 1977. Melmerby Research Restoration. Maritime Sediments, 13, pp. 33-36.

NELSON, C.L. and MILLER, R.L. 1975. The reaction of fluid and sediment on the foreshore. University of Chicago, Department of Geophysical Sciences, Fluid Dynamics and Sedimentary Transport Laboratory Technical Report No. 15, 176p.

OWENS, E.H. 1977. Temporal variations in beach and nearshore dynamics. Journal of Sedimentary Petrology, 47, pp. 168-190.

OWENS, E.H. and BOWEN, A.L. 1977. Coastal environments of the Maritime Provinces. Maritime Sediments, 13, pp. 1-32.
REED, W.E., LEFEVER, R. and MOIR, G.J. 1975. Depositional environment interpretation from settling velocity (Psi) distributions. Bulletin of the Geological Society of America, 86, pp. 1321-1328.

SHORT, A.D. 1979. Three-dimensional beach stage model. Journal of Geology, 87, pp. 553-571.

WRIGHT, L.D., CHAPPELL, J., THOM, B.G., BRADSHAW, M.P. and COWELL, P. 1979. Morphodynamics of reflective and dissipative beach and inshore systems, Southeastern Australia. Marine Geology, 32, pp. 105-140.

Reviewers: B.R. Pelletier D.J.W. Fiper 